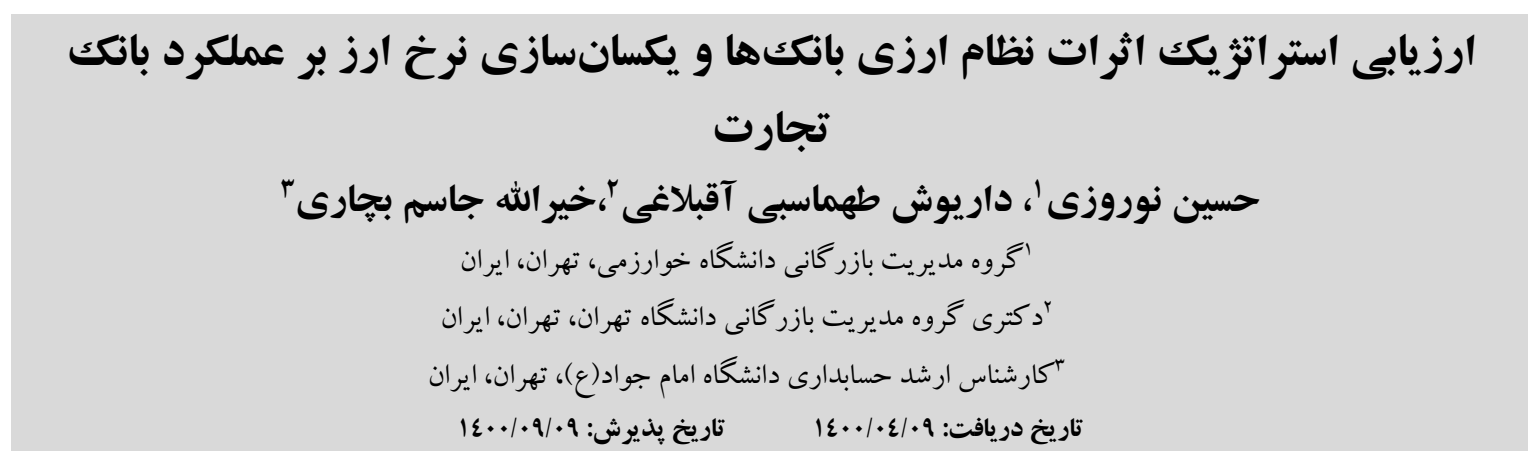

\title{
Strategic Evaluation Of The Effects Of Banks' Foreign Exchange System And Exchange Rate Unification On The Performance Of Tejarat Bank
}

\author{
Hossein Norouzi ${ }^{1}$, Dariush Tahmasebi Aghbelaghi ${ }^{2}$, Khirollah Jasembechari ${ }^{3}$ \\ Assistant Professor, Business Management Dep, Kharazmi University, Tehran, Iran \\ Ph.D. of Business Management Dep., university of Tehran, Tehran, Iran \\ Msc, of Accounting, University of Emam Javad, Tehran, Iran
}

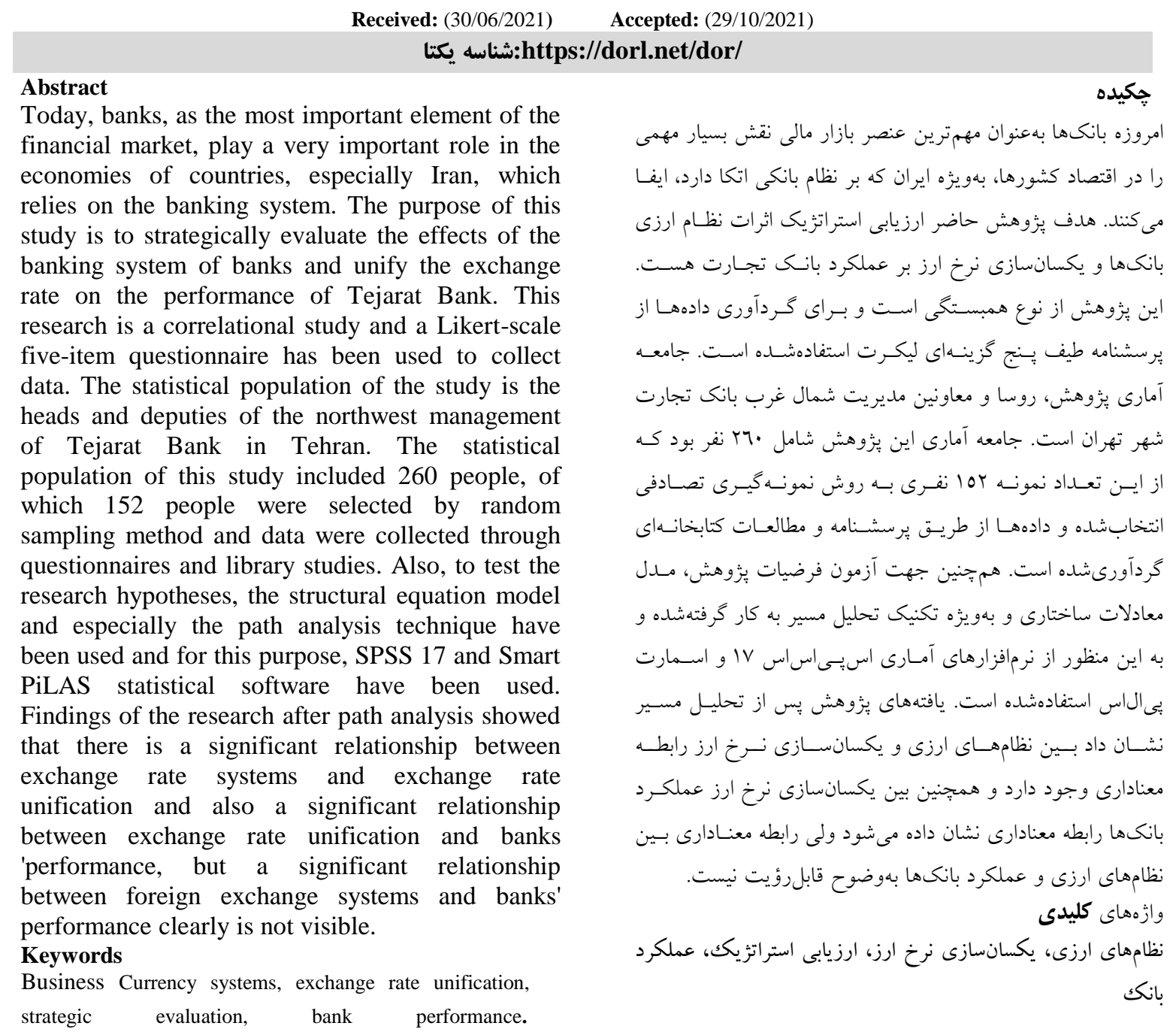


كزينه رزيم ارز شناور، كزينه اى كه اكثر كشورهاى ييشرفته

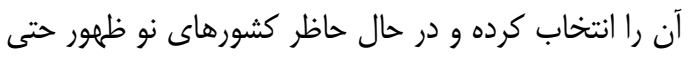

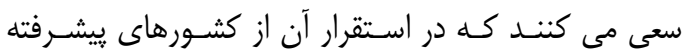
ييشى بخيرند. كشورى داراى نظام ارزى مطلوبى اسـت كـهـ

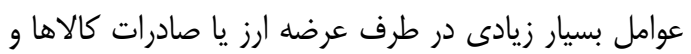

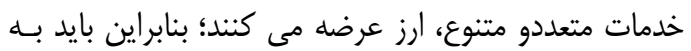

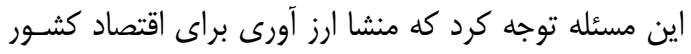

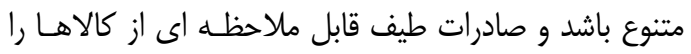

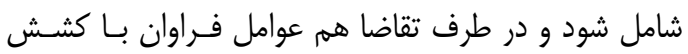

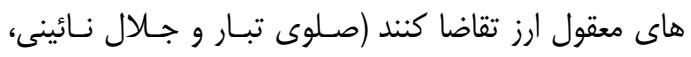

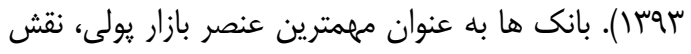

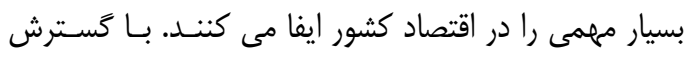

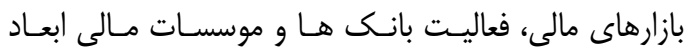

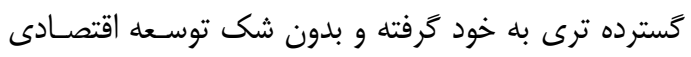

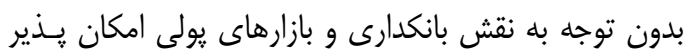

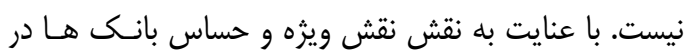

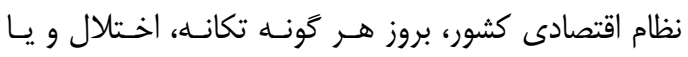
ناكارامدى در سيستم اقتصادى، مستقيما بر فعاليت بانك هـا

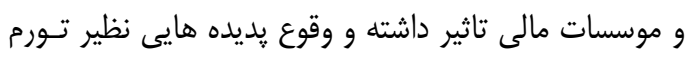
بالا و يا تكانه ها و نوسان هاى قيمتى شديد در ساير بازارها

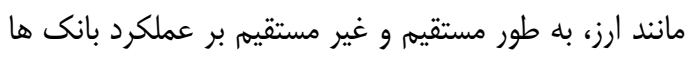

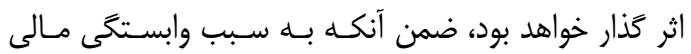

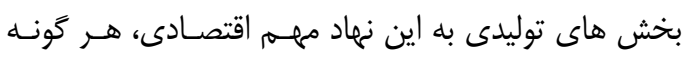

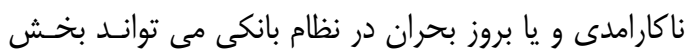

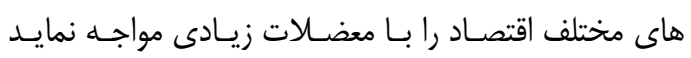

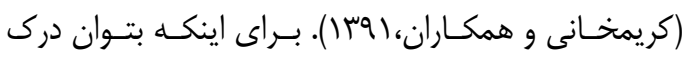

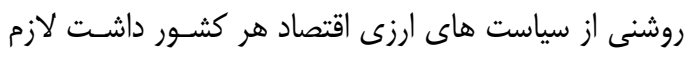

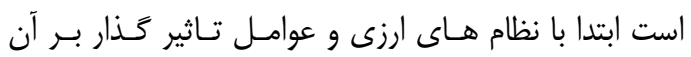

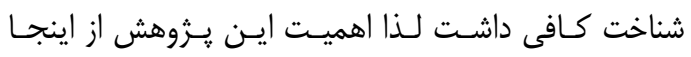

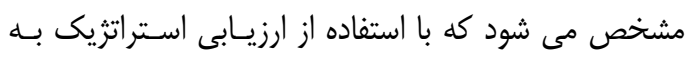

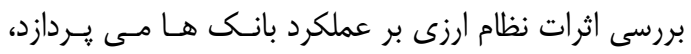

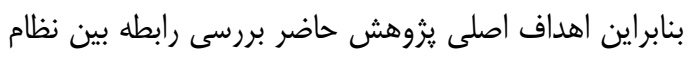

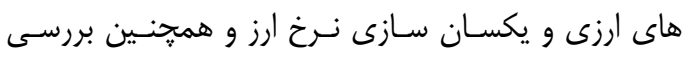

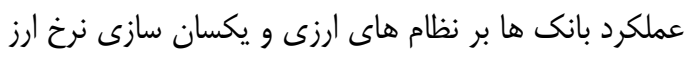

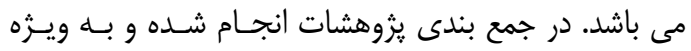

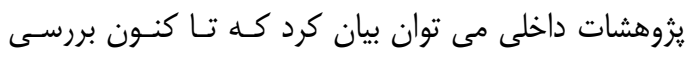

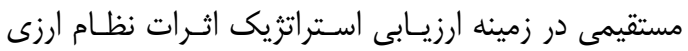

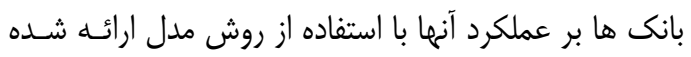

صورت نخَرفته است.

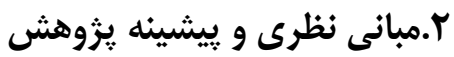

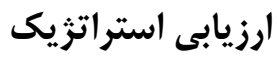

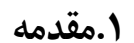

بانكها بهعنوان واسطهى مالى نقشى بسيار مهم در رشـــ و

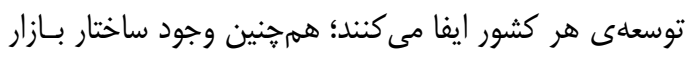

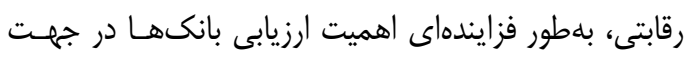

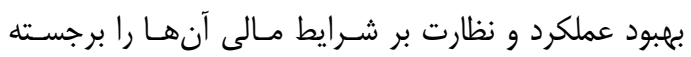

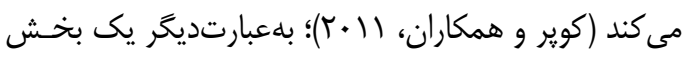

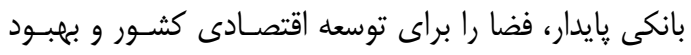

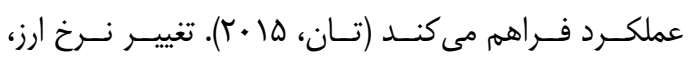

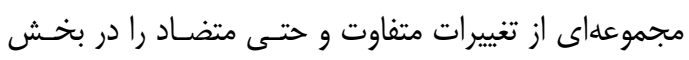

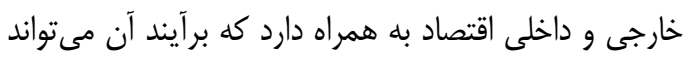
عملكرد اقتصاد كشور را تحت تأثير مثبت يا منفى قرار دهد.

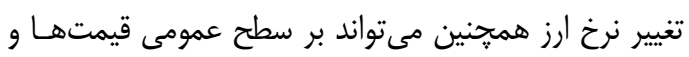

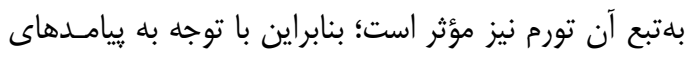

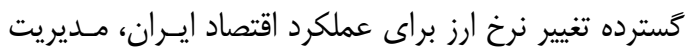
نرخ ارز اهميت بسيار بالايى دارد (مجلـه اقتصـادى، لوجسا).

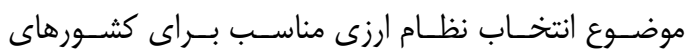
درحالتوسعه و توسعهيافته از مباحث مهـمه در ادبيـات ماليـهـ

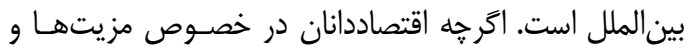
معايب نظامهاى ارزى مختلف، بحثهايى را مطرح نمودهاند

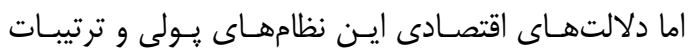

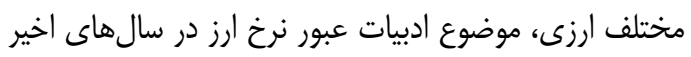

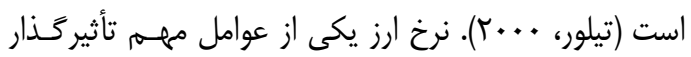

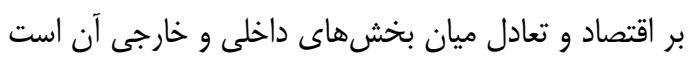

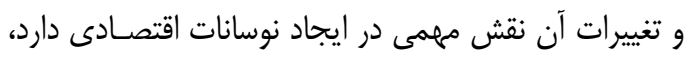

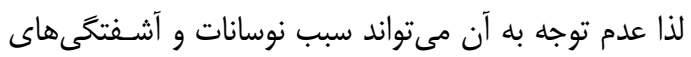

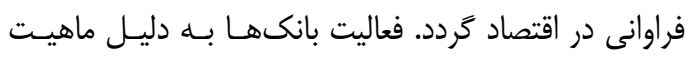

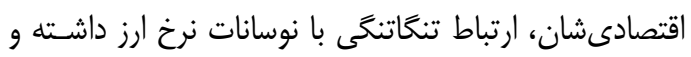

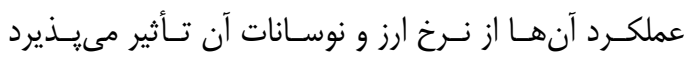

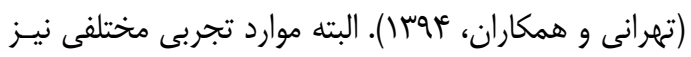

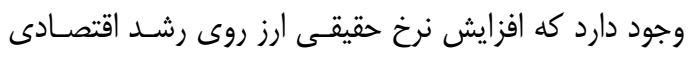

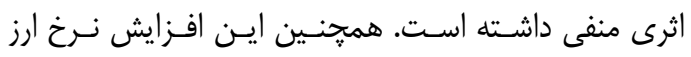

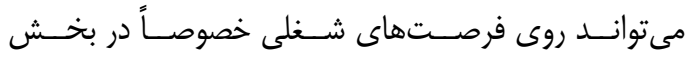

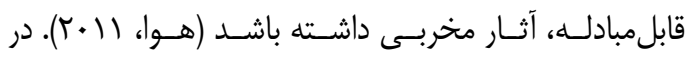

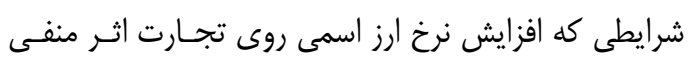

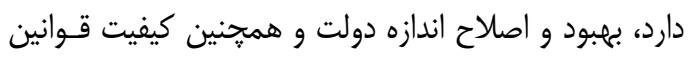

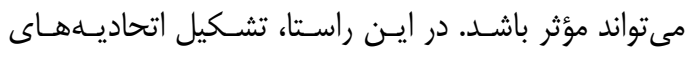
تجارى توسط كشورهاى ذينفع مىتواند آثار منفى نوسـانات

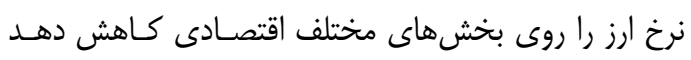

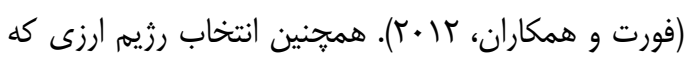

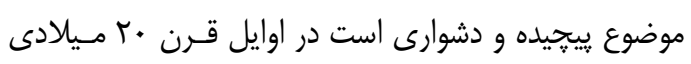

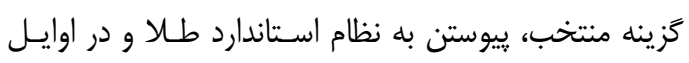
قرن ال ميلادى گزينه منتخب، رزيم نـرخ ارز شـناور بـود. 
تغييرات محيط با خبر شده و واكنش مناسب و سريع نشـان

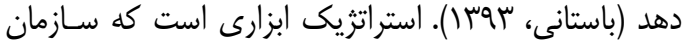

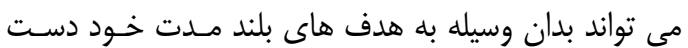

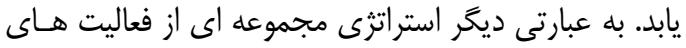
براى رسيدن به اهداف مورد نظر سازمانى مى باشد (هوتانا و إنى يلاس، ه + + (r).

\section{نظام هاى ارزى}

بحث رزيم ارزى از مهم ترين و تاثير كذار ترين مباحث در

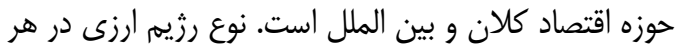

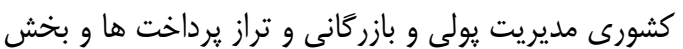

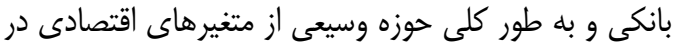

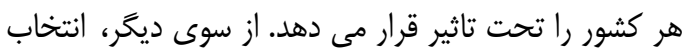
نوع رزيم ارزى نيز به نوبه خود تحت تاثير شرايط اقتصـادى

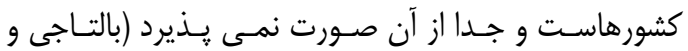

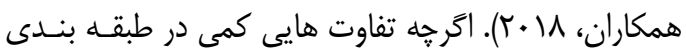

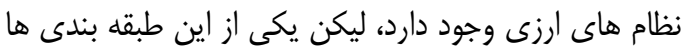

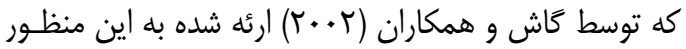

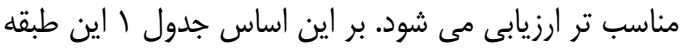
بندى شامل ه زير گروه و • إريم ارزى متفاوت است.
مفهوم ارزيابى از نظر لغوى وازهه ارزيـابى بـه معنسى تعيـين

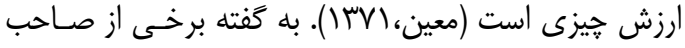

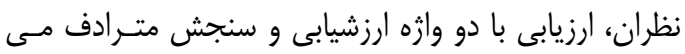

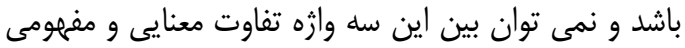

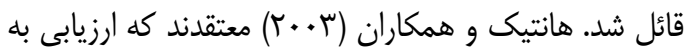

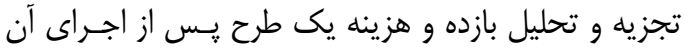

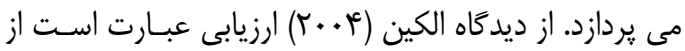
فراكرد تشخيص حيطهـ هـاى تصـميم گَيـرى مـورد نظـر،

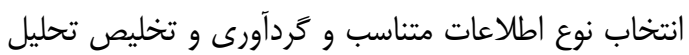
به منظور تهيه كزارش مناسب براى تصميم كَيرى. ارزيابى

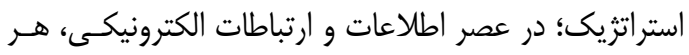

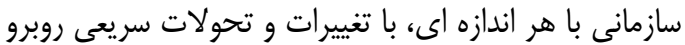

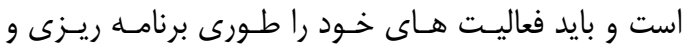
مديريت كند كه در محيط متلاطمه و بازار به شـدت ردابت رقابتى

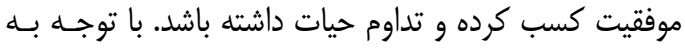

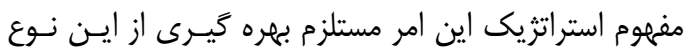

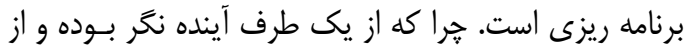
طريق ييش بينى تحولات آتى اقدامات مناسب را تنظيم مئى إنى

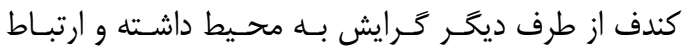

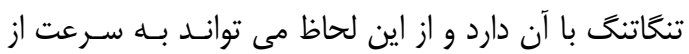

جدول (: طبقه بندى نظام هاى ارزى در يك نتخاه

\begin{tabular}{|c|c|c|}
\hline ويزگى هاى اصلى & نظام ارزى & طبقه بندى \\
\hline 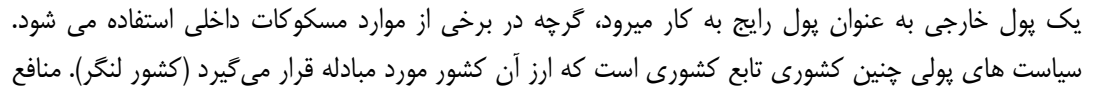 & دلاريزه كردن & 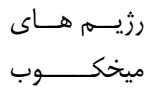 \\
\hline
\end{tabular}

نرخ ارز با نرخ برابرى كه در قانون مشخص شده به يك يول خارجى ميخكوب مى شود. در قانون حـــاقل ميـزان

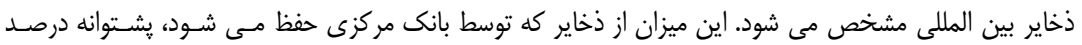

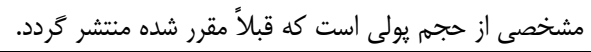

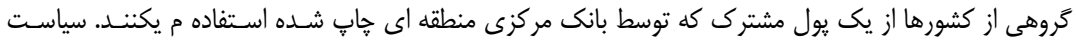

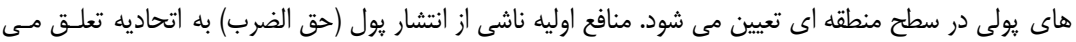

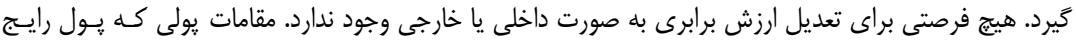
منتشر مى كنند مى توانند هر سياست نرخ ارزى رئ را دنبال كنند.

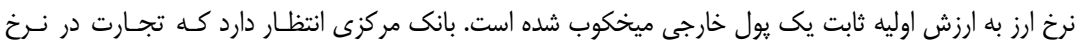

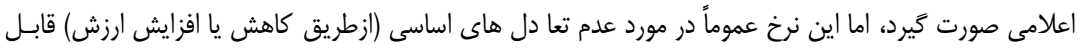

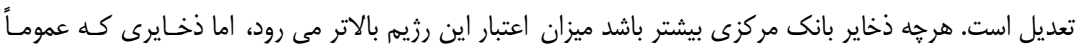

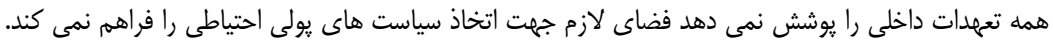

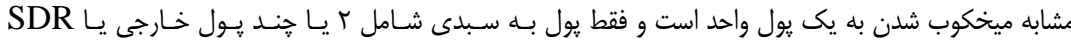

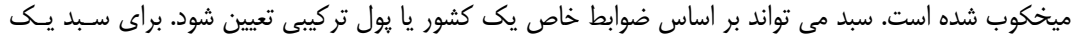

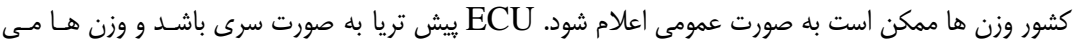
تواند ثابت يا متغير باشد.

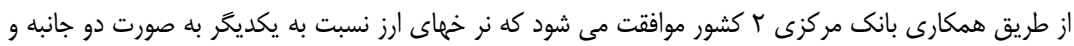

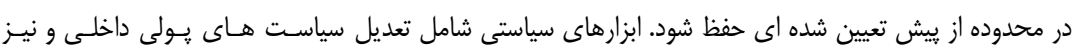

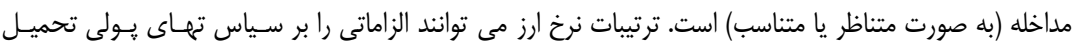

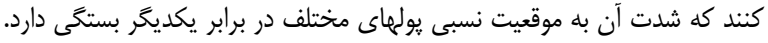

\section{ترتيبات با پشـتوانه}

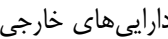

تحاديه يولى

ميخكوب بـه هـول

واحد

ميخكوب به سبدى

از ارزها

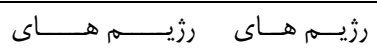
مشاركتى ميانه 


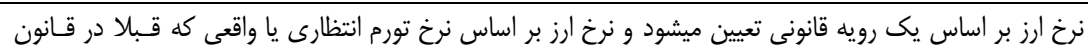
ميخكوب خزنده

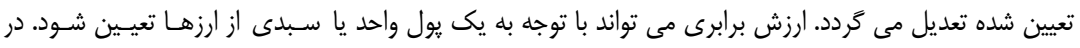

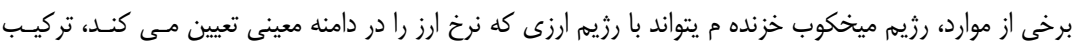

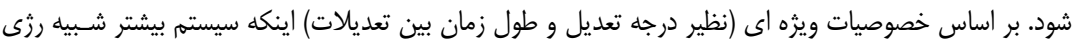
مهاى ثابت يا شناور است تعيين مى خرد درد.

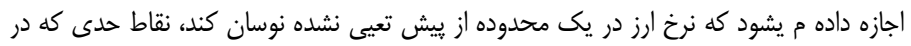
قلمرو يا نوار هدف

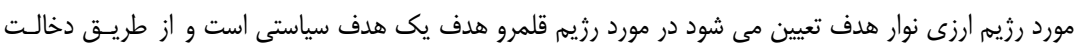

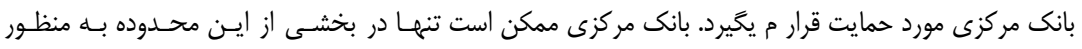

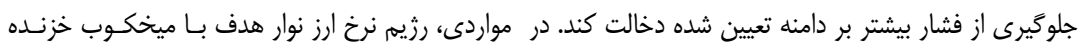

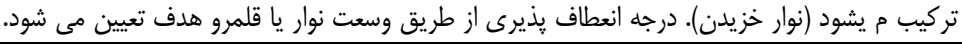

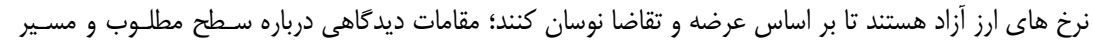

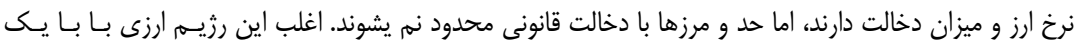

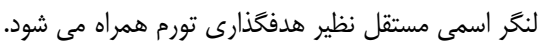

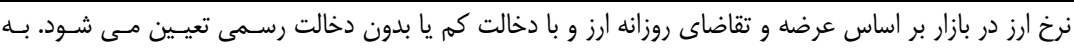
رزيسم هــاى شناور مديريت شده شناور

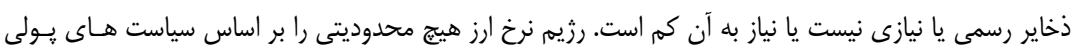
شناور مستقل

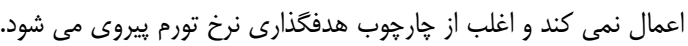

منحصر به فرد هر كثورى نيز ممكن اسـت تــاثيرات قابـل

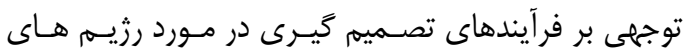

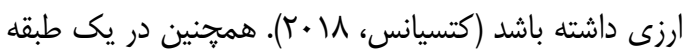

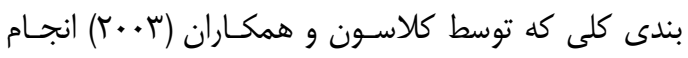

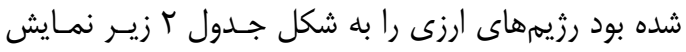
داده بوده اند.

\section{مولفه هاى موثر در انتخاب رزيم ارزى}

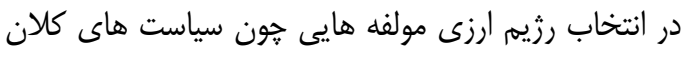

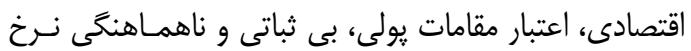

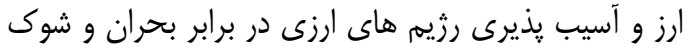

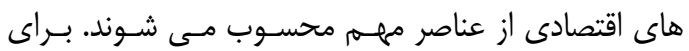

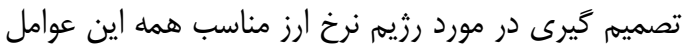

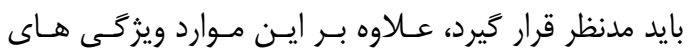

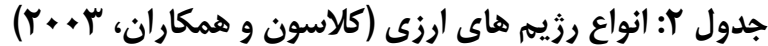

\begin{tabular}{|c|c|c|}
\hline رزيم هاى ارزى شناور & رزيم هاى ارزى ميانه & رثيم هاى ارزى ثابت \\
\hline شناور مديريت شده & ميخكوب قابل تعديل & اتحاديه يولى \\
\hline
\end{tabular}

\begin{tabular}{|c|c|c|}
\hline شناور آزاد & ميخكوب به سبدى از ارزها & \\
\hline & منطقه يا دامنه هدف & نظام كاملا ثابت \\
\hline
\end{tabular}

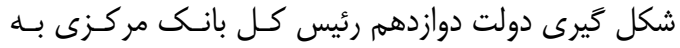
صراحت اعلام كرد تنها برنامه كليدى جامانده باند بانك مركزي

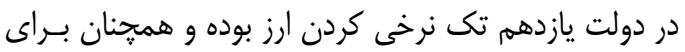

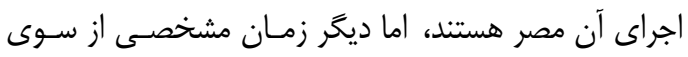
بانك مركزى براى يكسان سازى نرخ ارز اعلام نشد و تنهـا

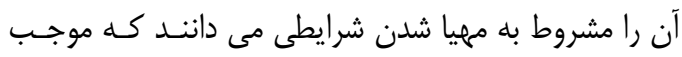

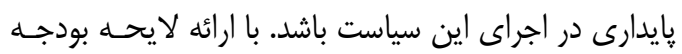

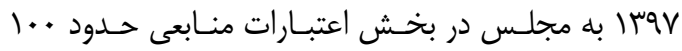

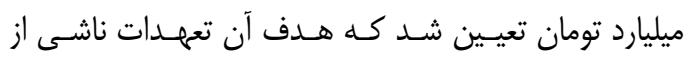
يكسان سازى نرخ ارز اعلام شده است، در نغاه اول ميتـوان

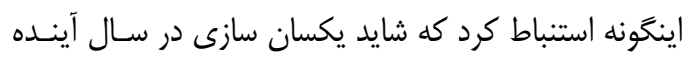

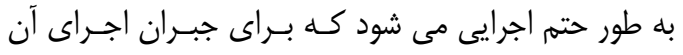

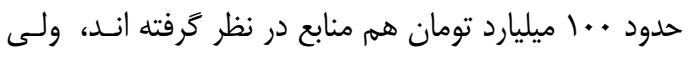
رئيس كل بانك مركزى اين را هم دليلى براى اعلام زمانى

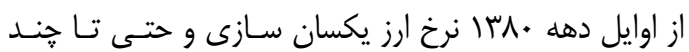

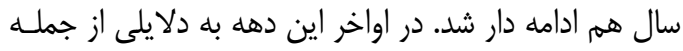

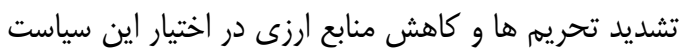

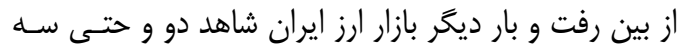

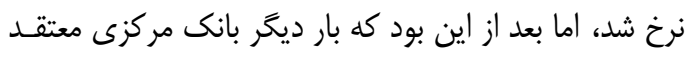

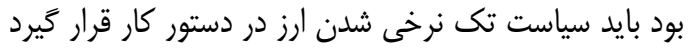

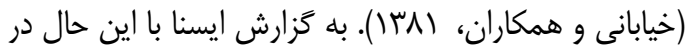

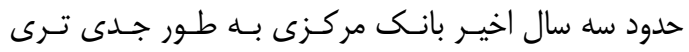

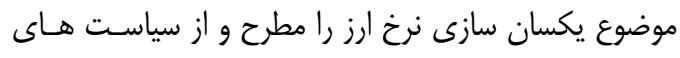

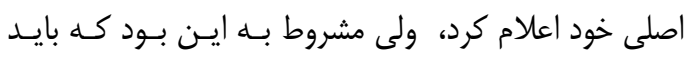

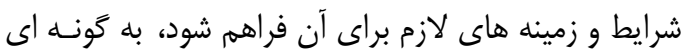

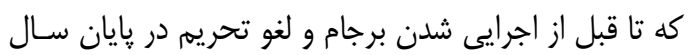

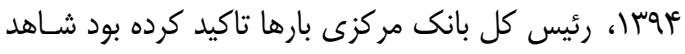

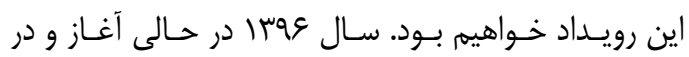




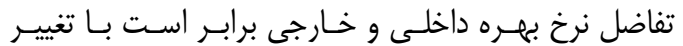

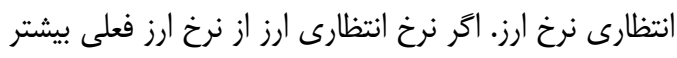

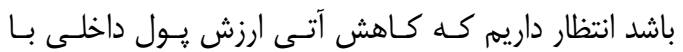

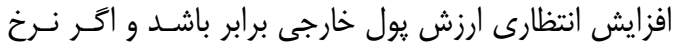

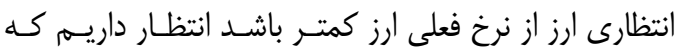

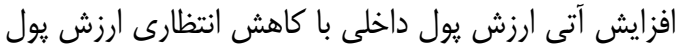

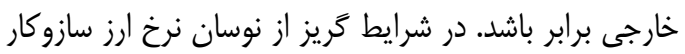

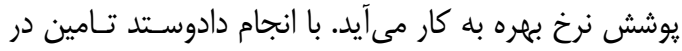

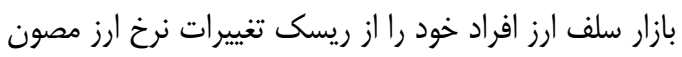

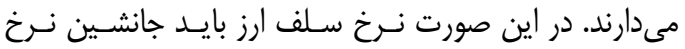
انتظارى ارز در معامله برابرى نرخ بهره شود (بلو و همكاران،

.$(r \cdot) \Lambda$

نظام هاى ارزى و يكسان سازى نرخ ارز

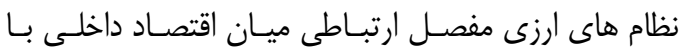

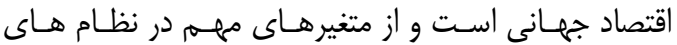

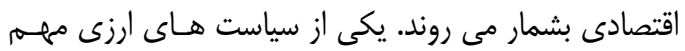
طى سال هاى اخير، سياست يكسان سازى نرخ ارز است كه إنها

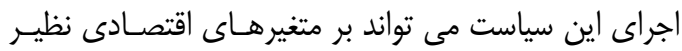
تورم، بيكارى، توليدو ... تاثير كذار بوده و در نتيجه شـرايط

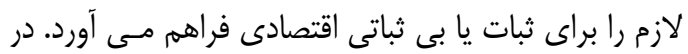

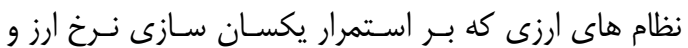

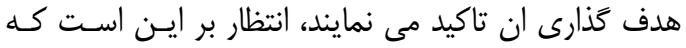

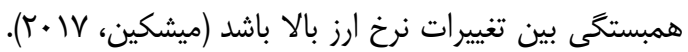

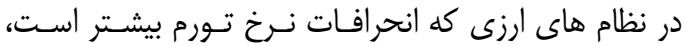

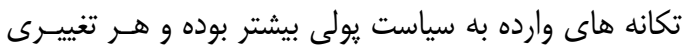

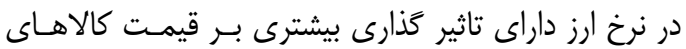

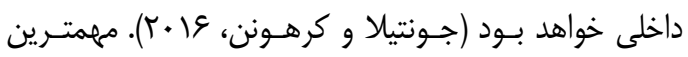
هدف يكسان سازى نرخ ارز، حذف رانت اقتصادى ناشسى از

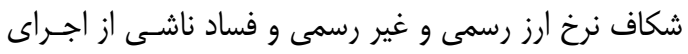

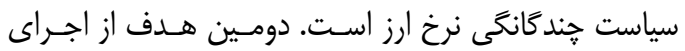

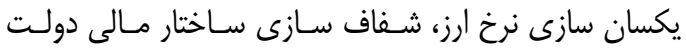

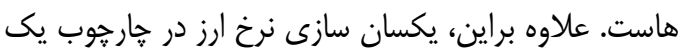

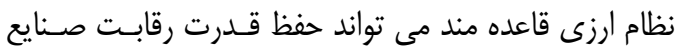

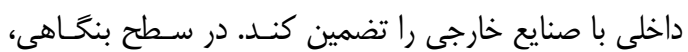

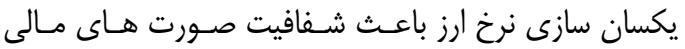

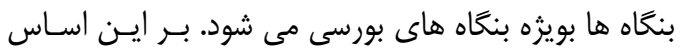

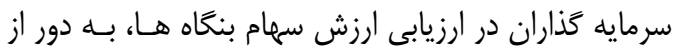

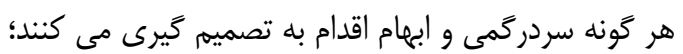

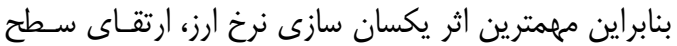

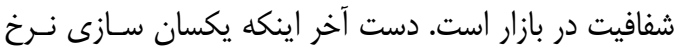
ارز رقابت يذيرى بنحاه هاى خصوصى را در رقابت با بنحَـاه هاى دولتى بهبود مى بخشد (حسكوئى، عوسا). نظريه هاى رئي
مشخص براى يكسان سازى نرخ ارز ندانسته و يـيش بينسى زمانى ندارد. وى تاكيد دارد كه وقتى زمينه هاى لازئ لازم آمـاده

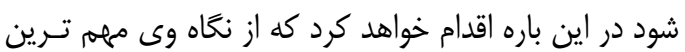
موضوع همان عادى شدن روابط بانكى در حوزه بين الملـل

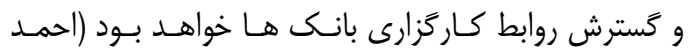

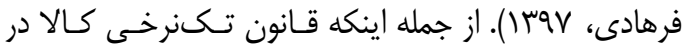

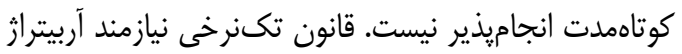

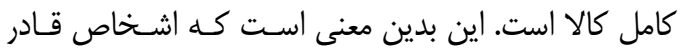
باشند كه هر كالايى راوارد و صادر كنند. اين كـالا بايـد در كارئ عين يكسان بودن از لحـاظ كيفى در كشـورهاى مختلـف، رانس،

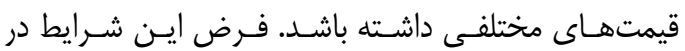

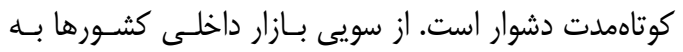

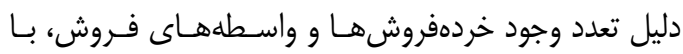

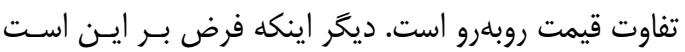

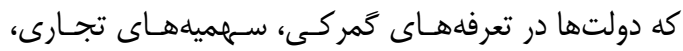

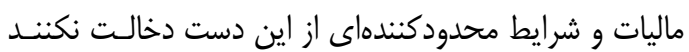

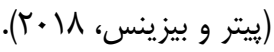

عملكرد بانكها

فعاليت بانكى ها به دليـل ماهيـت اقتصـادى شـان، ارتبـاط

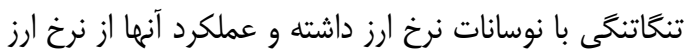

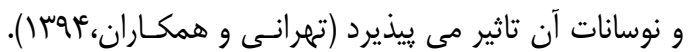

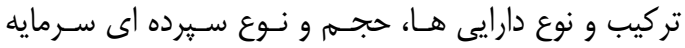

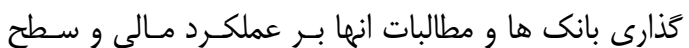

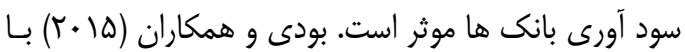

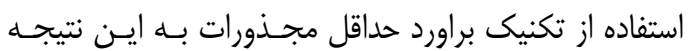

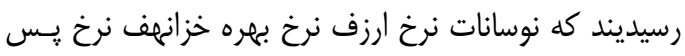

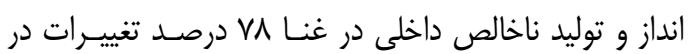

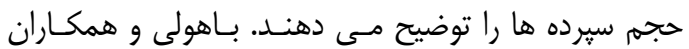

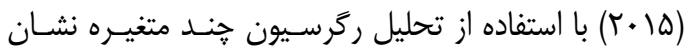

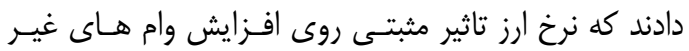

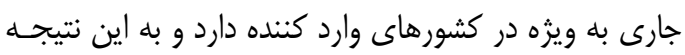
رسيدند كه ريسك نـرخ ارز اثـر معنـادارى روى عملكـرد و

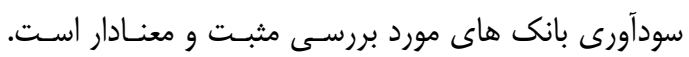
افزايش ارزش دارايىهاى ارزى خود موجب تقويت يول ملى مائ

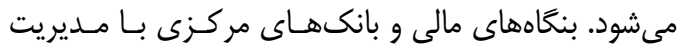

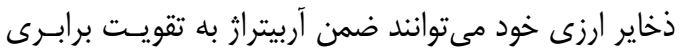
يول خود با ساير ارزها اقدام كنند. در يكى از معـاملات ايـن إنـ

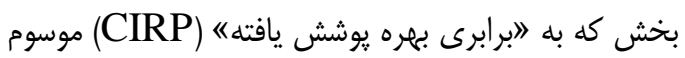

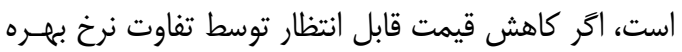

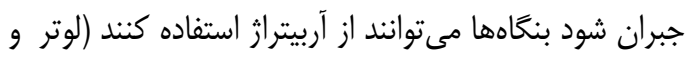

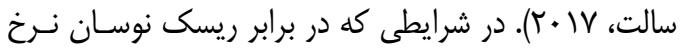

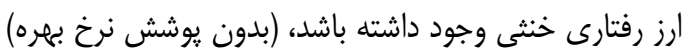


تفاوت كالا و صرفه هاى مقياس بـر سـودآورى و عملكـرد

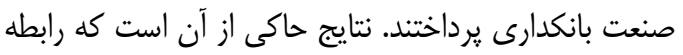

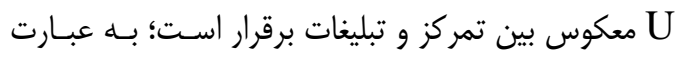

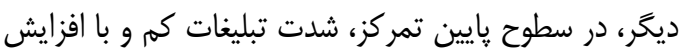

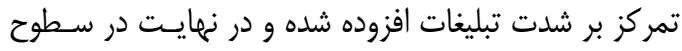
بالاى تمركز، مجددا شدت تبليغات كاهش مى يابد. لإنَات

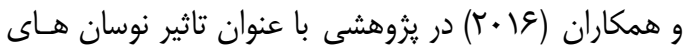

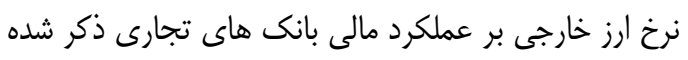

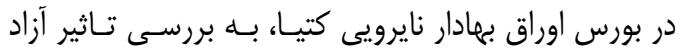

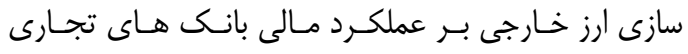

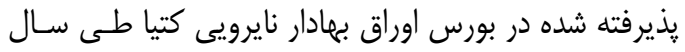

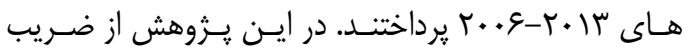
همبستخى ييرسون انى استفاده شده است. نتايج اين مطالعه

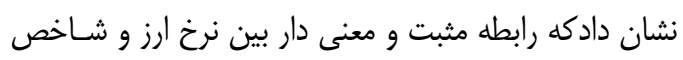

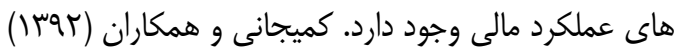

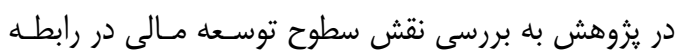

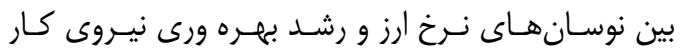

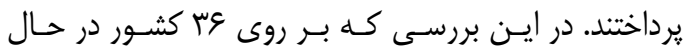

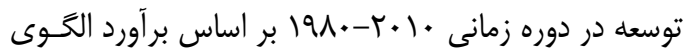
هانل يويا انجام شد، به اين نتيجه دست يافتند كه اثر نوسان

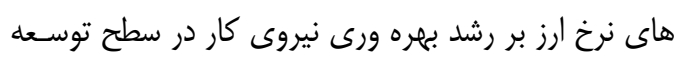

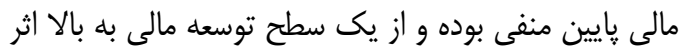

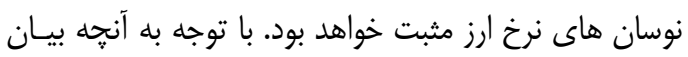

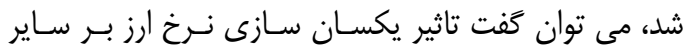

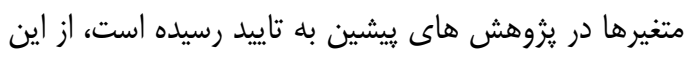

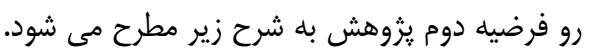

\section{فرضيه ؟َ: بين يكسان سازى نــرخ ارز و عملكــرد بانك ها رابطه اى معنادار است.

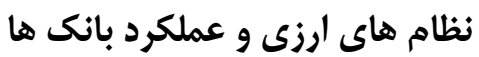

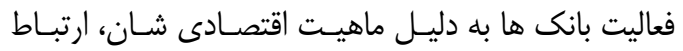

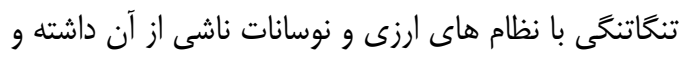

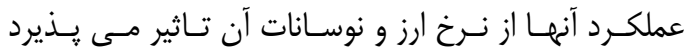

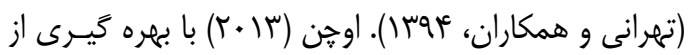

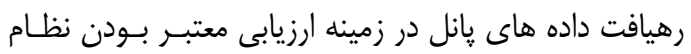

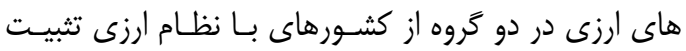

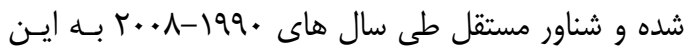
نتيجه مى رسد كه در كشورهاى با درجه بـاز بـودن اقتصـاد

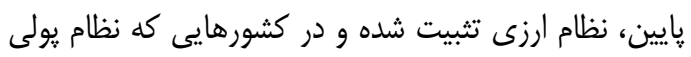
مبتنى بر هدف كذارى تورمى را تجربه نموده اند، نظام ارزى تئى

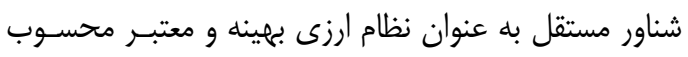

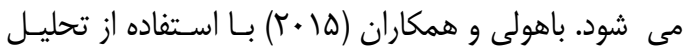

موجود درباره نظام هاى ارزى بيان مى كنند كه نظام هـاى

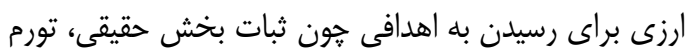

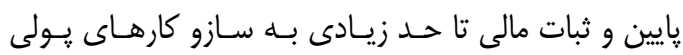

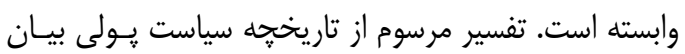

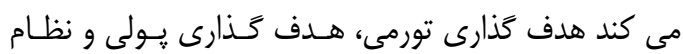
هاى ارزى خارجوب هاى رقيب براى تهاى سياست كذارى هستند

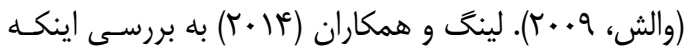

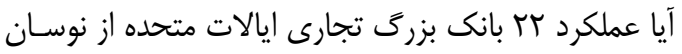

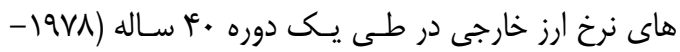

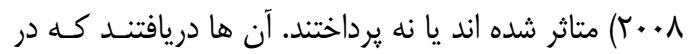

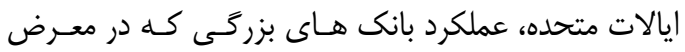

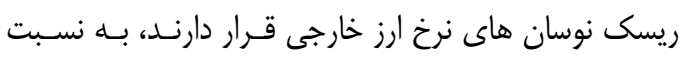

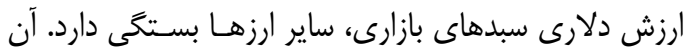

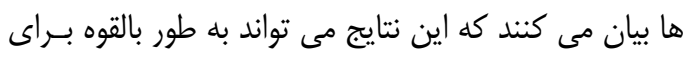

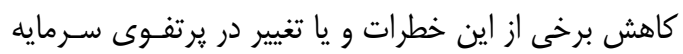

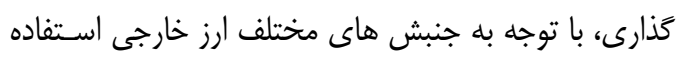

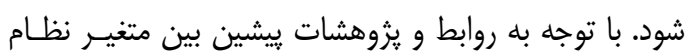

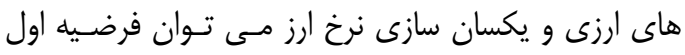
يزوهش حاضر را به شرح زير مطرح كرد:

\section{فرضيه ا: بين نظام هاى ارزى و يكســان سـازى

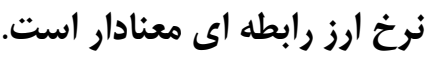 يكسان سازى نرخ ارز و عملكرد بانكى ها}

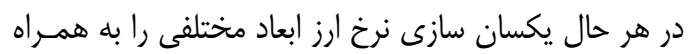

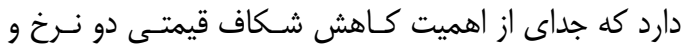

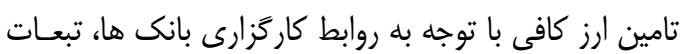

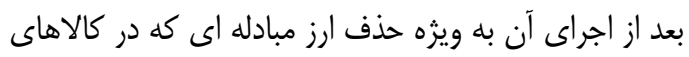

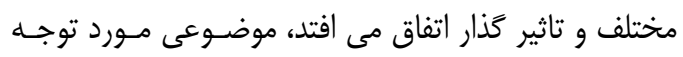

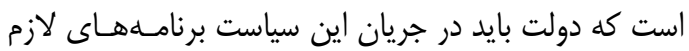

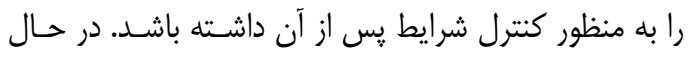
حاظر با توجه به اين كه بانك مركزى براى حذف ارد ارز مباد مبادله

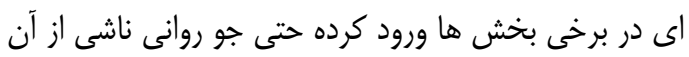

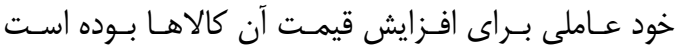

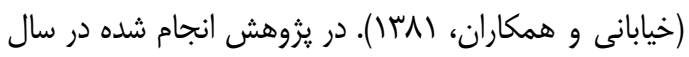

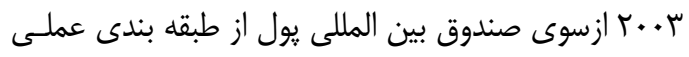
رزيم هاى ارزى استفاده شده است. اين طبقه بندى به به جاى إنى

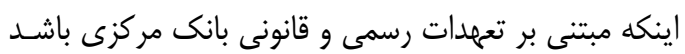
بر عملكرد واقعى آنها استوار است. نتايج اين مطالعه حـاكى بنى

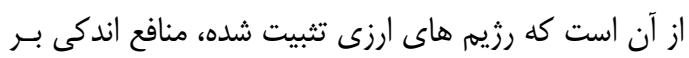

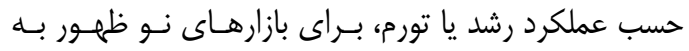

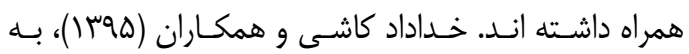
بررسى تاثير عناصر ساختارى همجئن تمركـز، موانع ورود، 


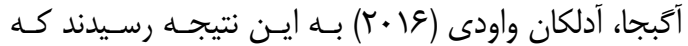

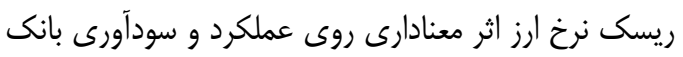

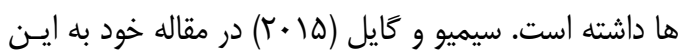

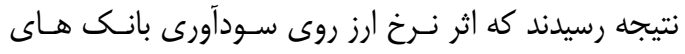

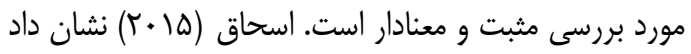
كه رابطه مثبتى بين تغييرات نرخ ارز و سود هـس از ماز ماليـات

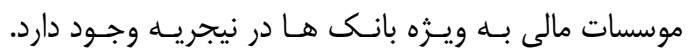

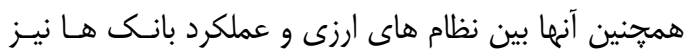

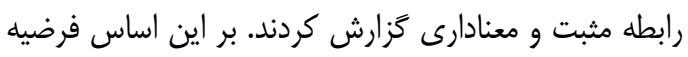
سوم يزوهش حاضر مطرح مى شود:

\section{فرضيه سا: بين نظام هاى ارزى و عملكرد بانك ها} رابطه ایى معنادار است. جدول س متغيرهاى اصلى اين يزوهش كه از ادبيات يزوهش إنش

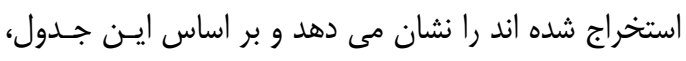
مدل مفهومى به شرح شكل ال ارائه مى شود.

ركرسيون جند متغيره نشان دادند كه نـرخ ارز تـاثير مثبتسى

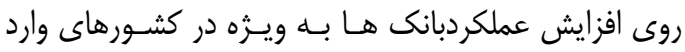

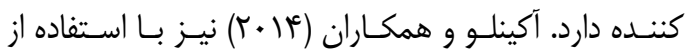
ركرسيون لكاريتمى به اين نتيجه رسيدند كه در نيجريه نرخ إندان

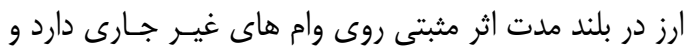

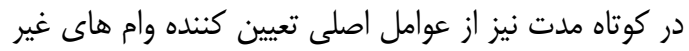

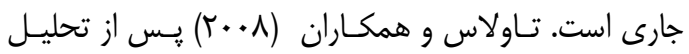
رويكردهاى مختلف شناسايى نظـام هـاى ارزى و انتــادات

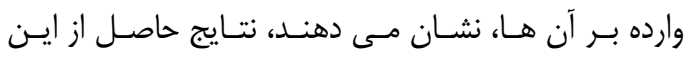

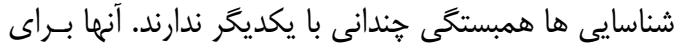

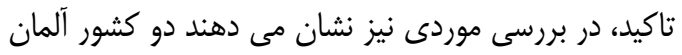
و ايتاليا تحت رويكردهاى متفاوت، به صورت هاى ناسئاز كاركار دسته بندى مى شوند. بر اساس مطالعات انجام شده توسط رونا

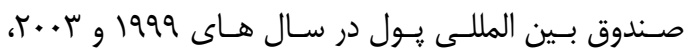
كشورهاى با رزيم هاى نرخ ارز تثبيت شده و ميانه بيشتر در

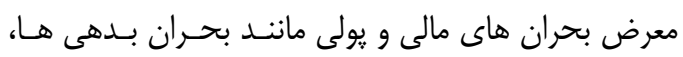
توقف ناكمانى ورود سرمايه يا بحران هاى بانى بانكى قرار دارند.

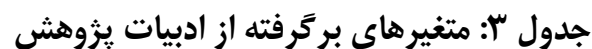

\begin{tabular}{|c|c|c|c|}
\hline بركَرفته از ادبيات يُوهش & ارتباط بين متغيرهاى مستقل و وابسته و & بركَرفته از ادبيات بُروهش & متغيرهاى يزووهش \\
\hline علوى تبار و جلال ضيايى (سوسا) & نظام هاى ارزى و يكسان سازى نرخ ارز & 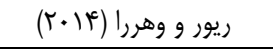 & نظام هاى ارزى \\
\hline ذوالفقارى و مهدى بهرام سجادى (هوا) & يكسان سازى نرخ ارز و عملكرد بانكما & 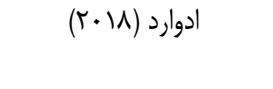 & يكسان سازى نرخ ارز \\
\hline خداداد كاشى و همكارن (هوج") & نظام هاى ارزى و عملكرد بانكها & آدلكان و اودى (1) (Y) & عملكرد بانكمها \\
\hline
\end{tabular}

نظام ارزى ثابت

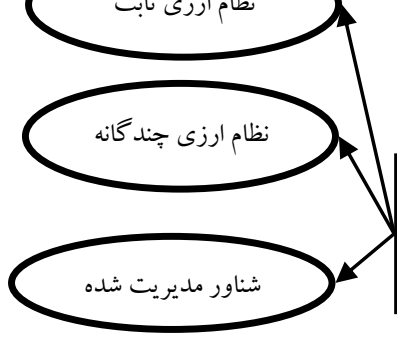

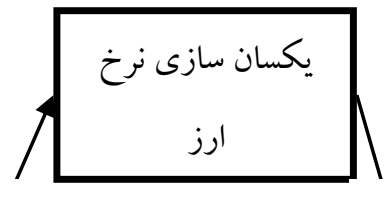

$\mathrm{H}_{1}$

نظامهاى ارزى

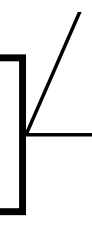

$\mathrm{H}_{2}$

\section{شكل (. مدل مفهومى ثيزوهش}

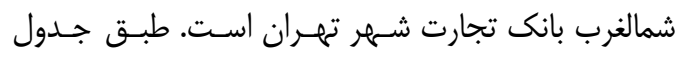

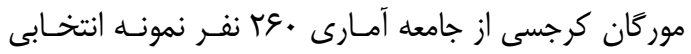

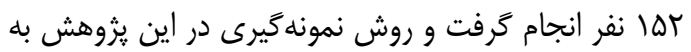

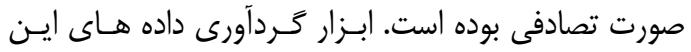

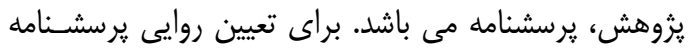

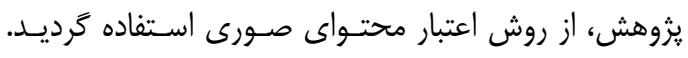

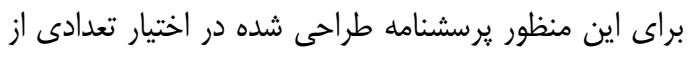

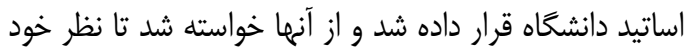

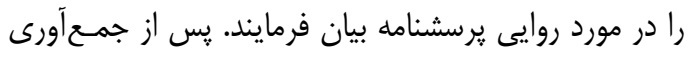

"ا.روش شناسى يزوهش يروهش حاضر از حيث هدف كاربردى است و از حيث نحوة

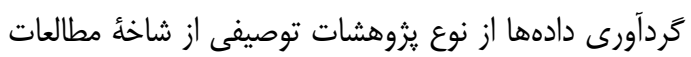

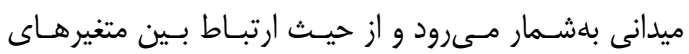

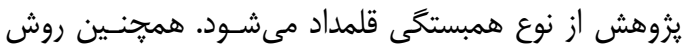

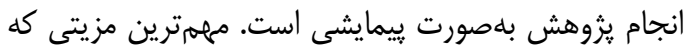

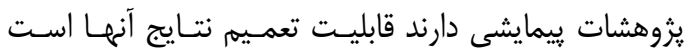

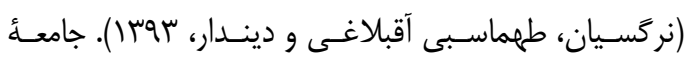

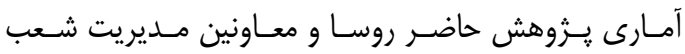


بيش از نيمى از واريانس شاخصهـاى (متغيرهـاى آشـكار)

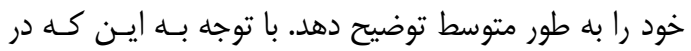

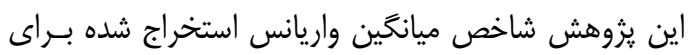

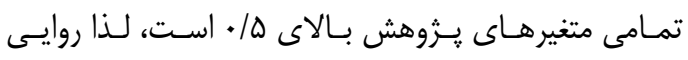

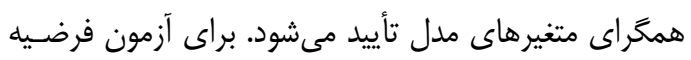

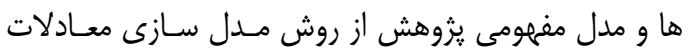

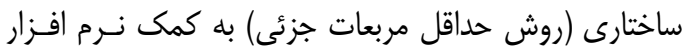

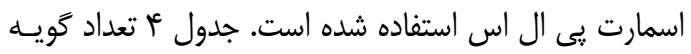
ها و نتايج پايايى يزوهش حاضر را لنشان مىدهد.

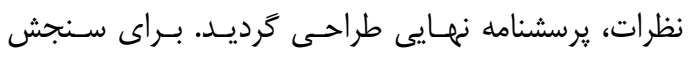

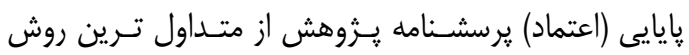

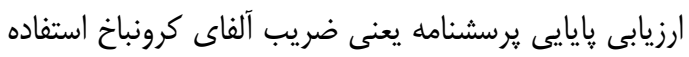

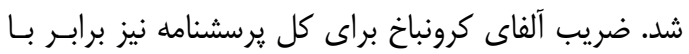

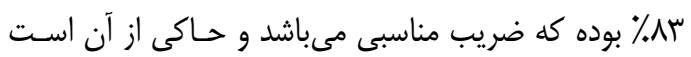

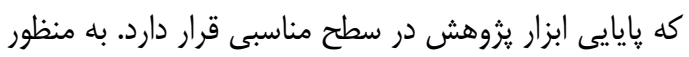
محاسبه روايى همخرا، از معيار ميانگين واريـانس استـتخراج

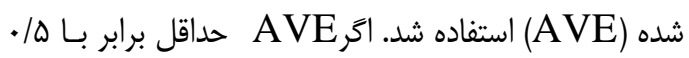
باشد، بيانكر آن است كه متغيرها از روايى همكَراى مناسبى

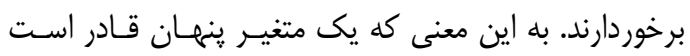

جدول ع.متغير هاى يزوهش و منابع استخراج تويه ها و نتايج بايايى ابزار تردآورى دادهها

\begin{tabular}{|c|c|c|c|c|c|c|}
\hline ضريب آلفاى & CR & AVE & منبع استخراج كَويه ها & طيف & كَويهها & متغير \\
\hline.$/ \mathrm{VV}$ &.$/ A r$ & .191 & محقق ساخته & ينج گزينهاى ليكرت & 8 & نظام هاى ارزى \\
\hline.$|\wedge|$ &.$/ \wedge \Delta$ &.$/ \Delta$ & الهيارزاده(سوسا) & ينج گزينهاى ليكرت & 19 & يكسان سازى نرخ ارز \\
\hline \multirow[t]{2}{*}{.119} &.$/ \mathrm{M}$ &.$/ 4 F$ & مارتينز و همكاران(ه + (T) & ينج گزينهاى ليكرت & 8 & عملكرد بانكها \\
\hline & & & & & ru & كل يرسشنامه \\
\hline
\end{tabular}

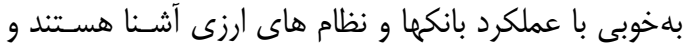

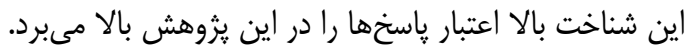

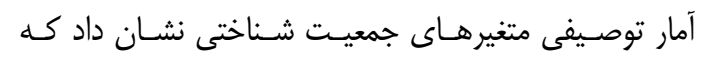

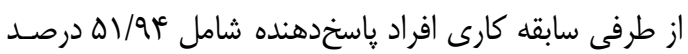

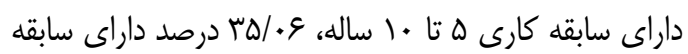

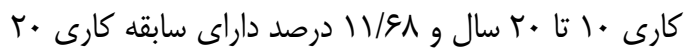

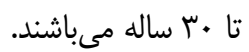

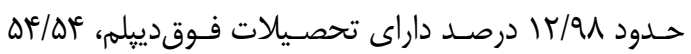

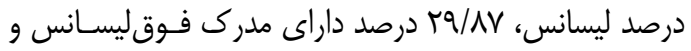

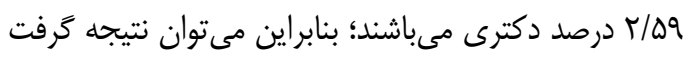

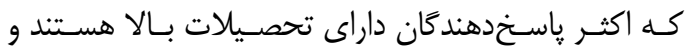

جدول ه.اطلاعات توصيفى متغيرهاى يزوهش

\begin{tabular}{|c|c|c|c|c|}
\hline : جولخى & كشيدگى & انحر اف معيار & ميانگين & 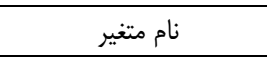 \\
\hline.$- / T \Delta Q$ &.$/ \omega \Delta \Delta$ &.$/ \wedge \Delta$ & $r / N$ & نظام هاى ارزى \\
\hline.$- / T \mu q$ &.$- / v 94$ &.$/ A r$ & $r / 4 \wedge$ & ثابت \\
\hline.$- / T \Delta F^{c}$ & אוMF &.$/ V \Delta$ & $r / 9 \mid$ & جندكًانه \\
\hline . &.$- / F r \Delta$ &.$/ \Lambda$ & $r / A r$ & شناور مديريت شده \\
\hline$-1 / V 9$ & $1 / \wedge \varepsilon$ & $.9 \mathrm{~V}$ & $r / \Delta \xi$ & يكسان سازى نرخ ارز \\
\hline -l\&Ar &.$- / V 9 D$ & .190 & $r / v$. & عملكرد بانكها \\
\hline
\end{tabular}

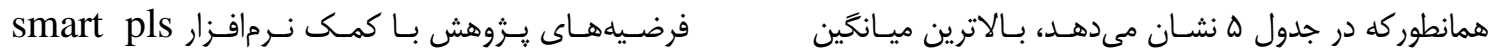
استفادهشده است. نمودارهاى ا و r ضريب مسير اسـتاندارد

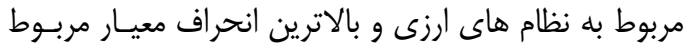

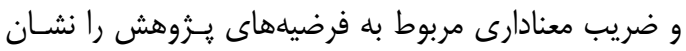

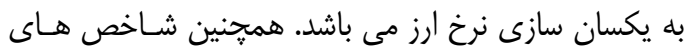




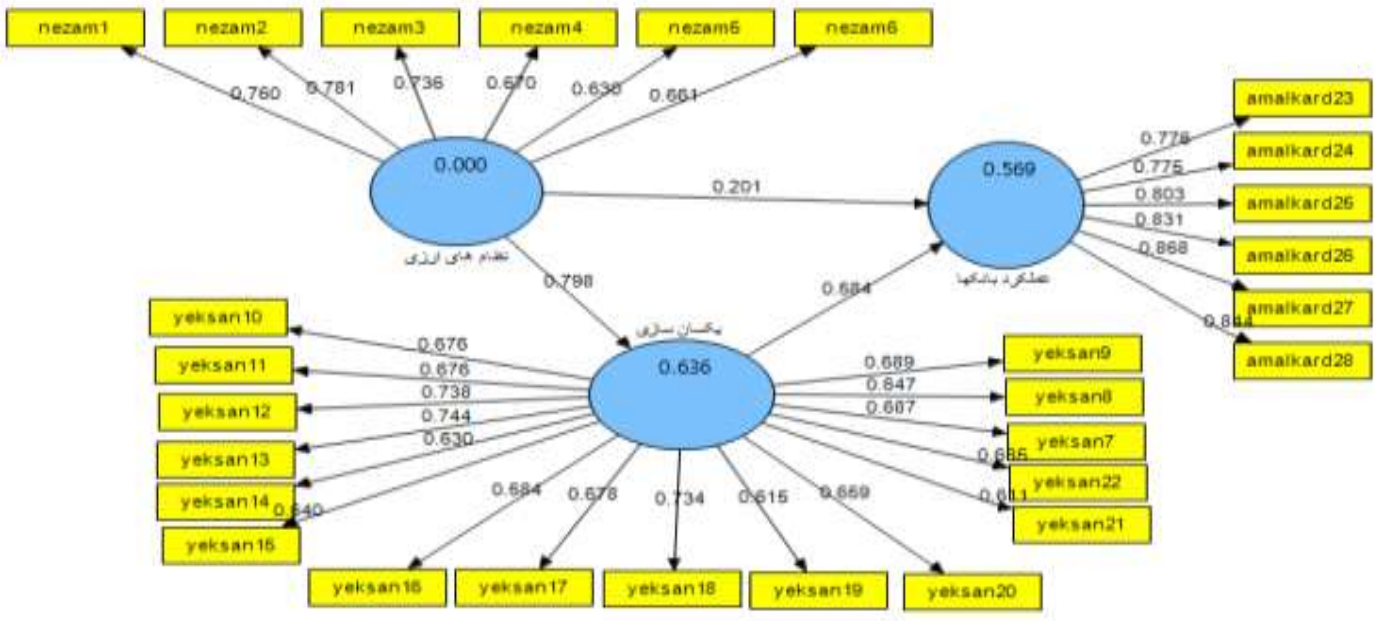

\section{نمودار (. تحليل مسير}

وابسته بيشتر مىباشد؛ بنابراين مى تـوان كَفـت كـه متغيـر

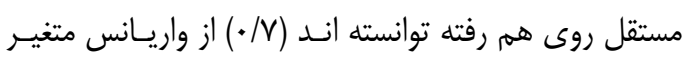

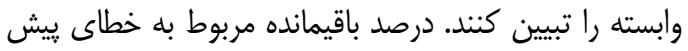

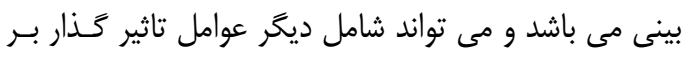

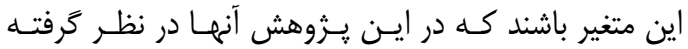

نشدند.
اعداد داخل بيضى شاخص ضريب تعيين مىباشـنــ. ضـريب

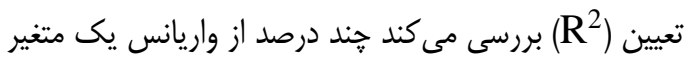

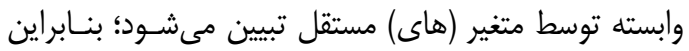

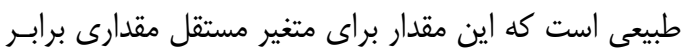

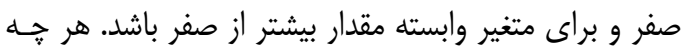

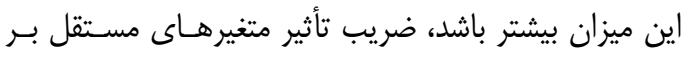

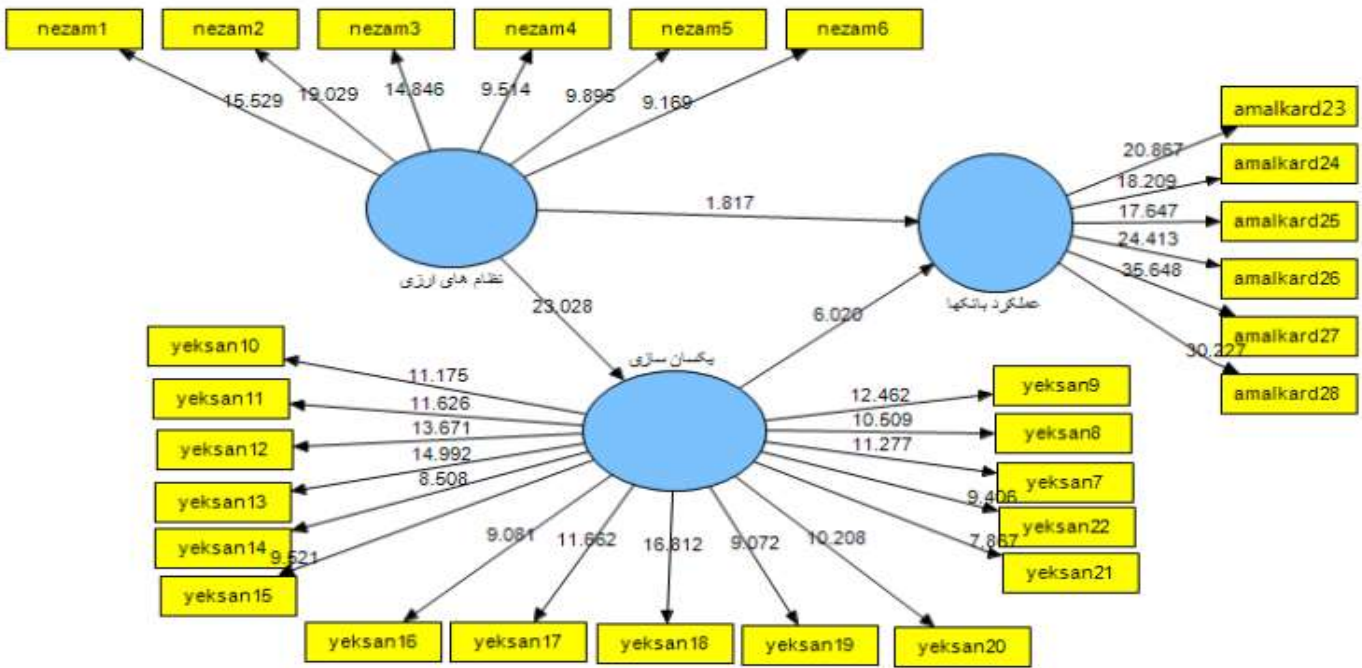

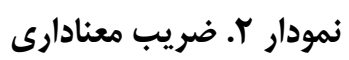

مقدار وه/ بيشتر است كه اين مطلب حكايـت از معنىدار

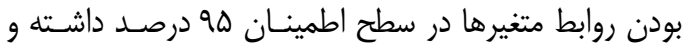

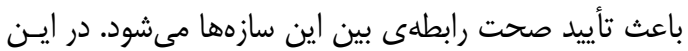

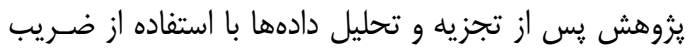

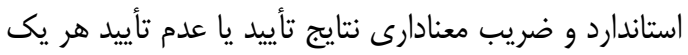
از فرضيههاى يزوهش بلهورت جدول 8 آورده شده است.
همان كَونه كه در نمودار r قابلمالاحظه اسـت، رابطـهـ بـين

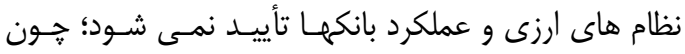

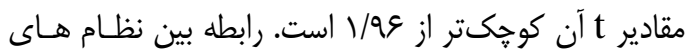
ارزى و يكسان سازى نرخ ارز و همجنين رابطه بين يكسان

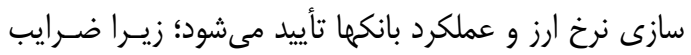

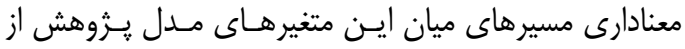

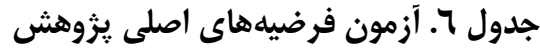

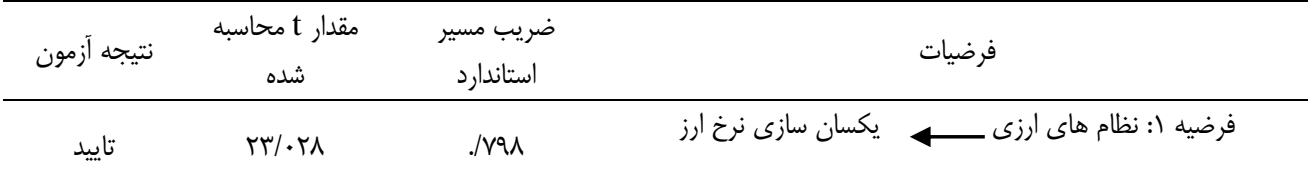




\begin{tabular}{|c|c|c|c|c|}
\hline تاييد & gl.r. &.$/ \Delta \wedge \uparrow$ & عملكرد بانكها & فرضيه r: يكسان سازى نرخ ارز ــ \\
\hline د) & $1 / \mathrm{A} / \mathrm{V}$ &.$/ r \cdot 1$ & عملكرد بانكمها & 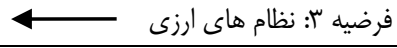 \\
\hline
\end{tabular}

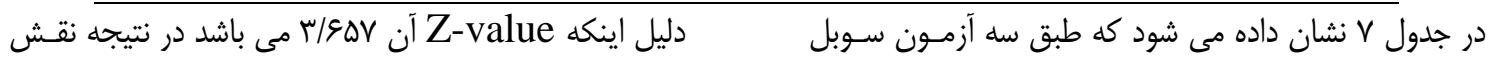

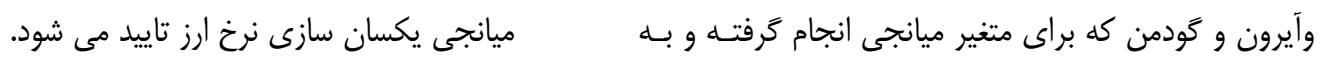

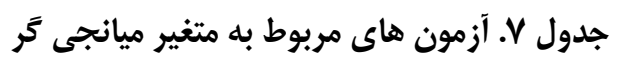

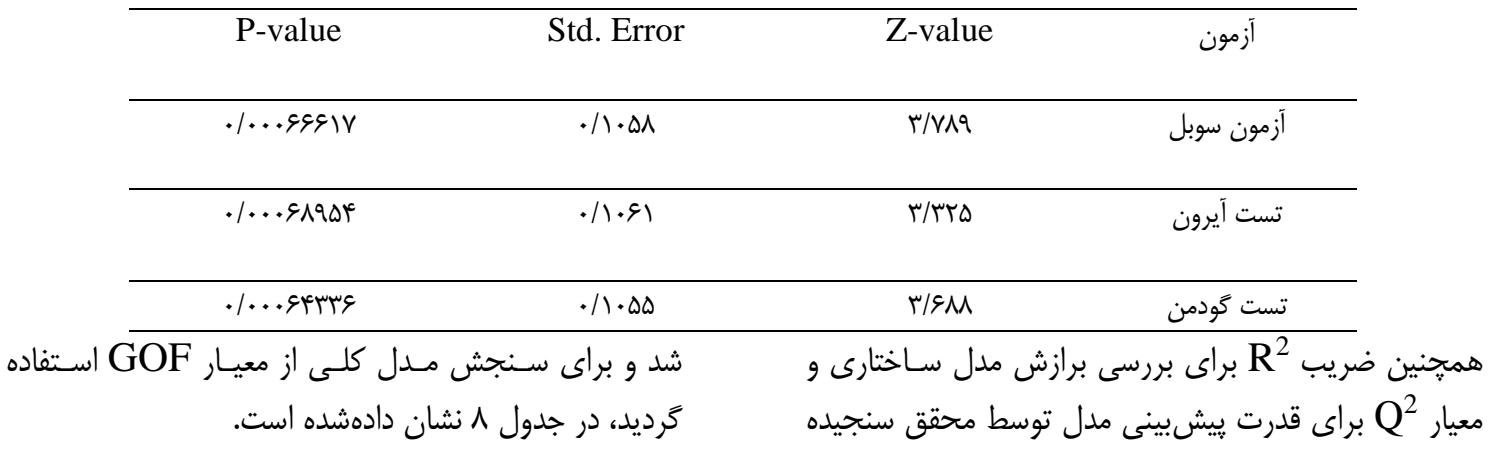

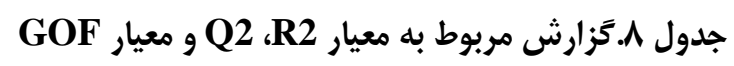

\begin{tabular}{|c|c|c|c|c|c|c|c|c|c|}
\hline \multicolumn{3}{|c|}{ GOF } & \multicolumn{3}{|c|}{ Q معيار Q2 } & \multicolumn{3}{|c|}{ معيار R Squares } & \multirow{3}{*}{ متغير } \\
\hline عس/. & $\cdot / T \Delta$ & $.1 \cdot 1$ & D &.$/ 10$ &.$/ \cdot r$ & $.19 \mathrm{~V}$ & س س &.$/ 19$ & \\
\hline قوى & متوسط & ضعيف & قوى & متوسط & ضعيف & قوى & متوسط & ضعيف & \\
\hline & \multirow{2}{*}{ - $/ 9 t^{4}$} & & & - /Fmegh & & & ع ع ع|. & & يكسان سازى نرخ ارز \\
\hline & & & & . /TqVYFF & & & - $1 \Delta \& 9$ & & عملكرد بانكها \\
\hline
\end{tabular}

نرخ ارز يكى از مهـهم تـرين ابزارهـاى سياستى دولـت هـا

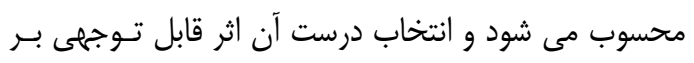

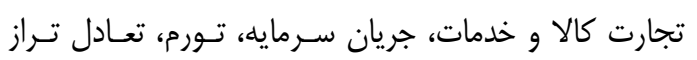

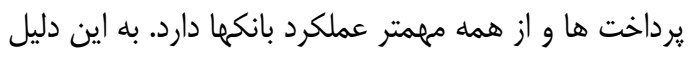

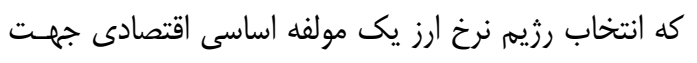

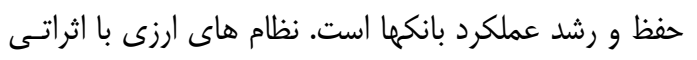

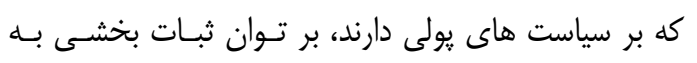

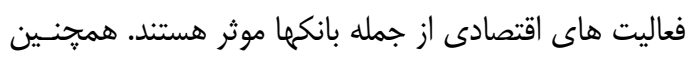

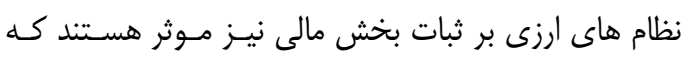

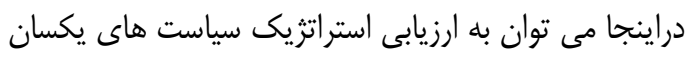

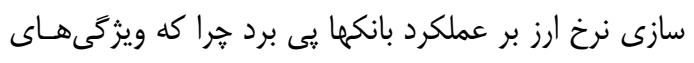

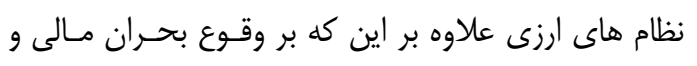

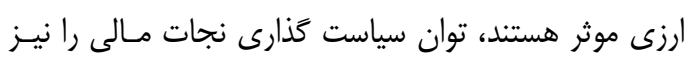

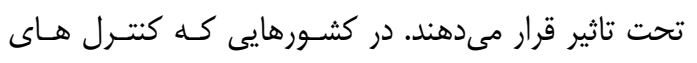

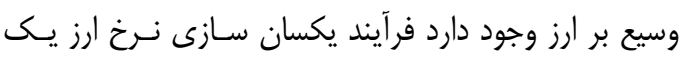

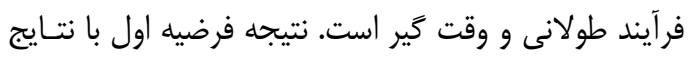

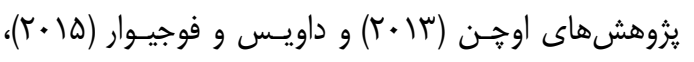

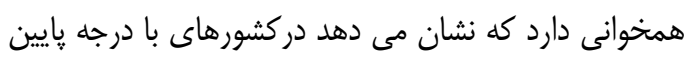

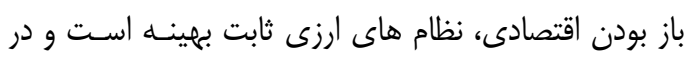

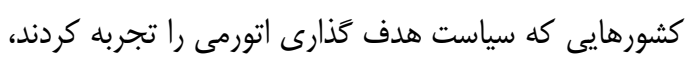

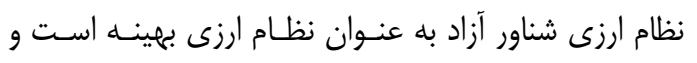

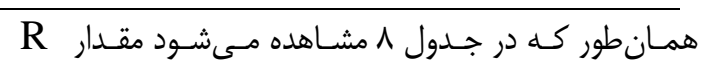

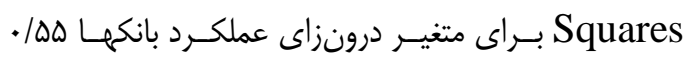

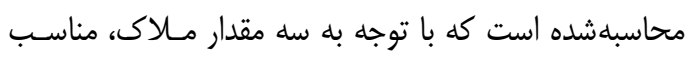

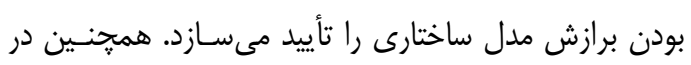

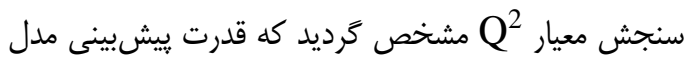

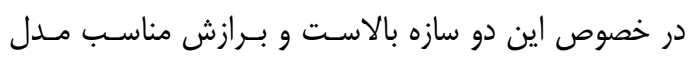

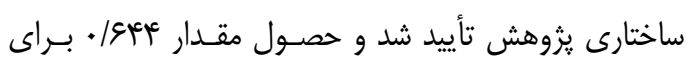
معيار GOF، بـرازش بسـيار مناسـب مـدل كلـى را نشــان

\section{ع.نتيجه كَيرى و بيشنهادها}

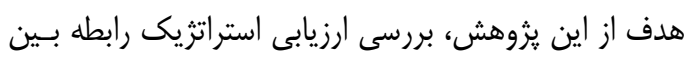

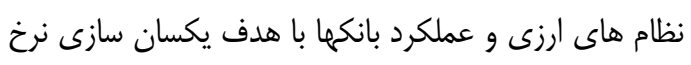

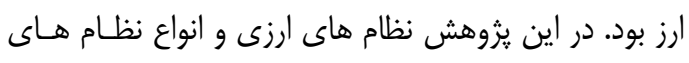

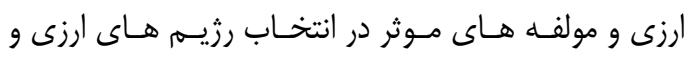

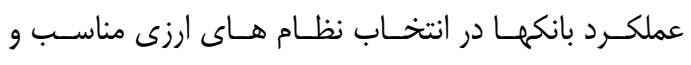

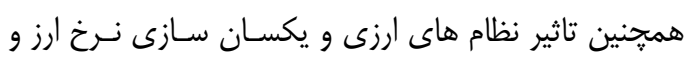

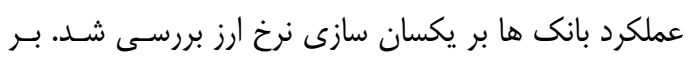

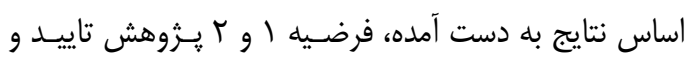

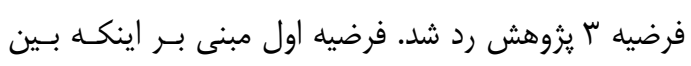

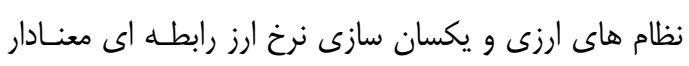

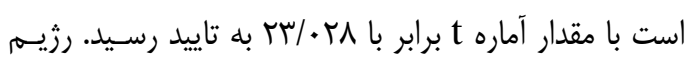


بانكها داشته باشد، زيرا تاثير نوسان نظام هاى ارزى با روش

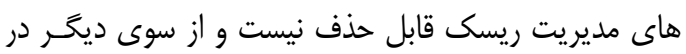

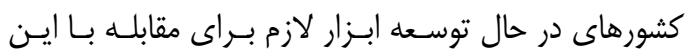

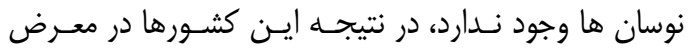

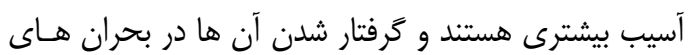

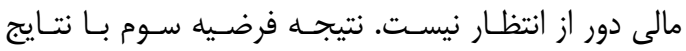

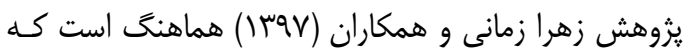

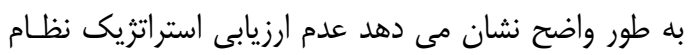

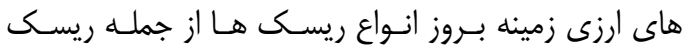

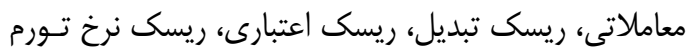

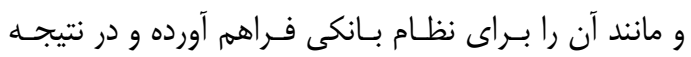

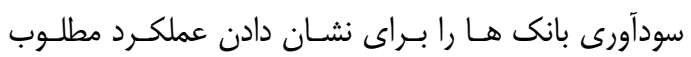

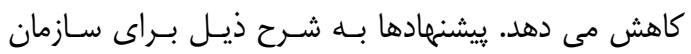

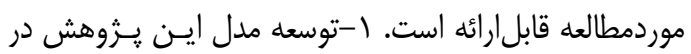

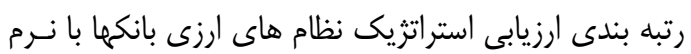

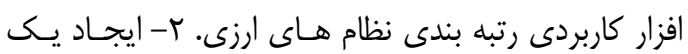

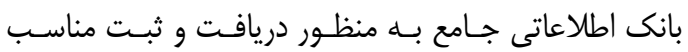
دادهاى سنجش ارزيابى استراتزيكى نظام هاى ارزى بانكهـا

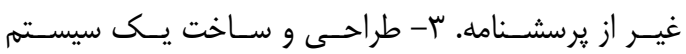

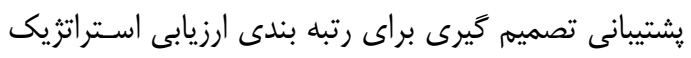

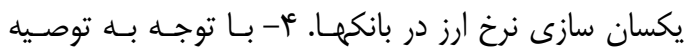

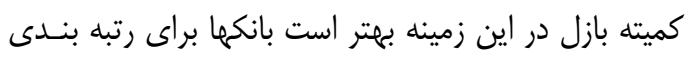

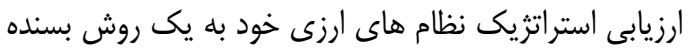

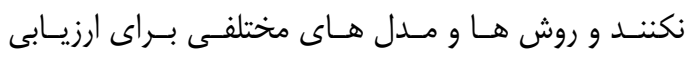

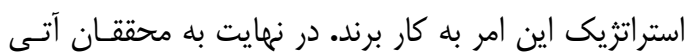

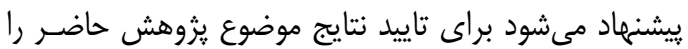

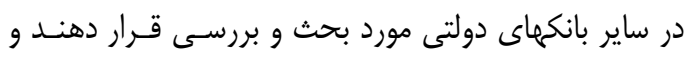

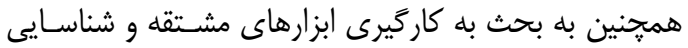

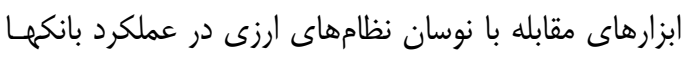

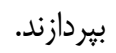

منابع بوستانى، رضا (اوسו). سياست كذارى يولى برينه در اقتصاد ايران. يزوهش هاى يولى و بانكى.

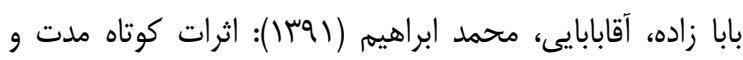

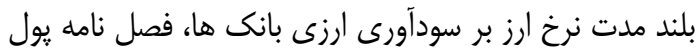
و اقتصاد، 9. ذوالفقارى، مهدى و سحابى (هوسا)، بررسى تاثير نوسانات نرخ إنها

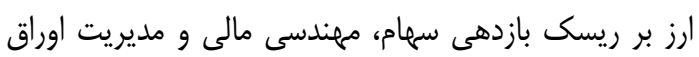

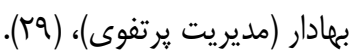

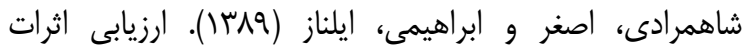

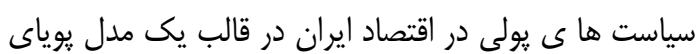
تصادفى نيوكينزى. مجموعه مقالات بيستمين كنفرانس
همجنين هدف گذارى تورم منجر به رفاه اجتماعى بالاتر مى

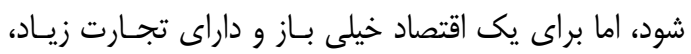

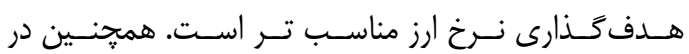

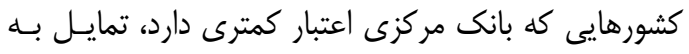

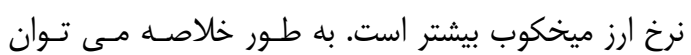

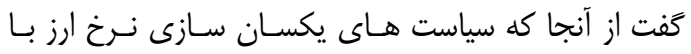

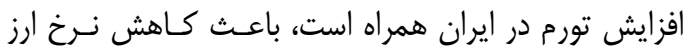

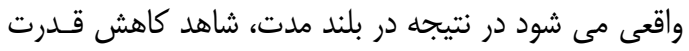

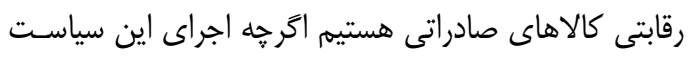

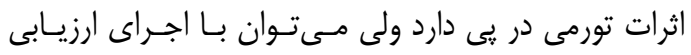

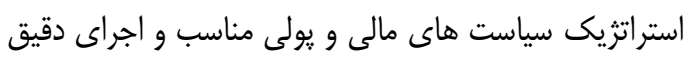

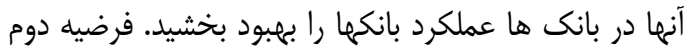

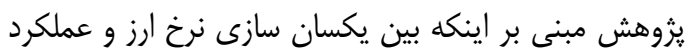

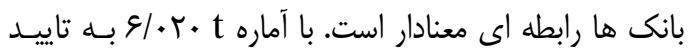

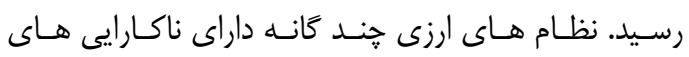

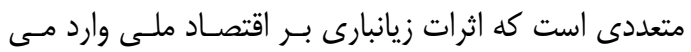

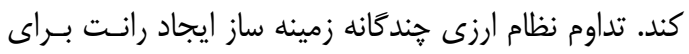

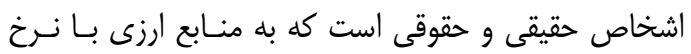

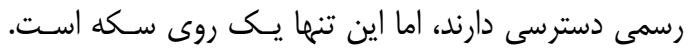

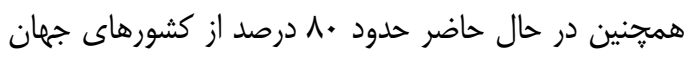
با ارزيابى استراتزيك داراى نظام ارزى تكى نرخى مى بـ باشند

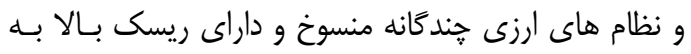

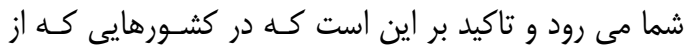
يك نوع نظام ارزى مشخص استـفاده مسى شـود و يكسـان

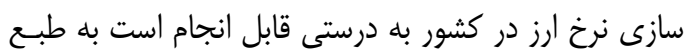

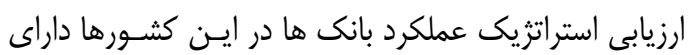

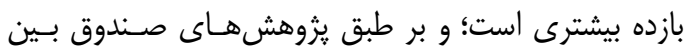

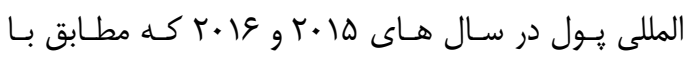

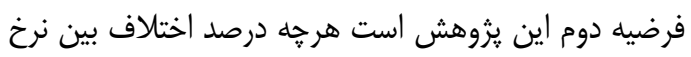

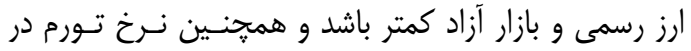

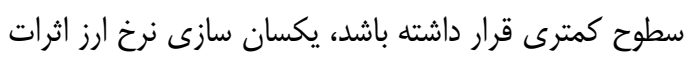

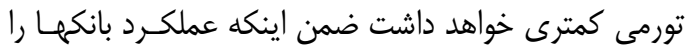

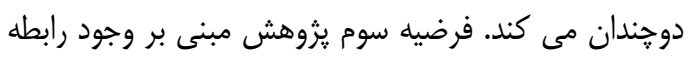

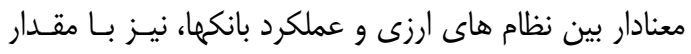

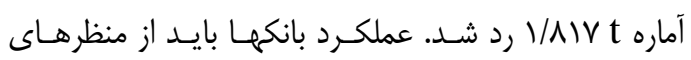

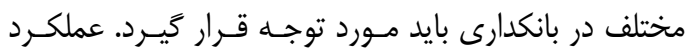

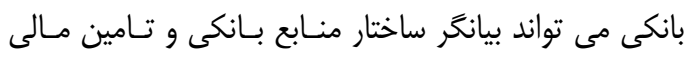

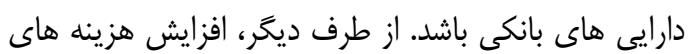

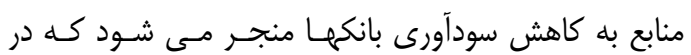

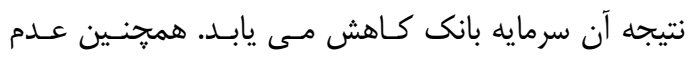

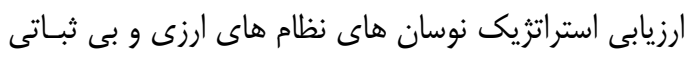

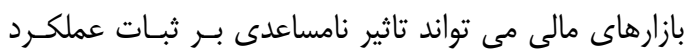


Impact of Exchange Rate Volatility on the Macroeconomic Variables in Negeria; European scientific journal, 9(7): 152.165

Broto, Carment \& Berganza, Juan Carlos (2011). Flexible Inflation Targets, Interventions and Exchange Rate Volatility in Emerging Countries; Banco DE-Espana Eurosistema.

Baltaji, M(2018). on the analytical and comparison of the types of exchange rate regimes from the economic point of the different countries.

Celasun oya.exchange rate regime considerations in an oil economy: the case of thi Islamic republic of iran. (January 2003):1-18 .

Catsianc, G( 2018 ). view of the foreign exchange regimes and the factors that affect the selection of the appropriate currency regime.

Chisepeya, H( 2013 ). Effects Of Currency Exchange Rate, Inflation On Performance Of Commercial Banks In Malawi, The Thesis Submitted In Partial Fulfilment Of The Requirements For The Award Of The Degree Of Masters In Baking And Finance, Moi University.

Fayman , A . and Michael Casey , K . ( 2014 ). Bank Profitability : The Impact of Foreign Currency Fluctuations, Journal of Applied Business and Economics, vol . 16 , No. 2 , PP . 98 104.

Fogarasi, Jozsef \& Ferto, Imre (2012). On Trade Impact of Exchange Rate Volatility and Institutional Quality: The Case of Central European Countries AESI, Dublin .

Giannellis , N and Papadopoulos , A.P. ( 2011 ) : What causes exchange rate volatility ? Evidence from selected EMU members and candidates for EMU membership countries.Journal of International Money and financ , 30 , 39 -61 .

Korinekjane \& Huchet Bourdon, Marilyne (2011). To What Extent Do Exchange Rates and Their Volatility Affect

$$
\begin{aligned}
& \text { سالانه سياست هاى يولى و ارزى. يزوهشكده يولى و بانكى جانى } \\
& \text { بانك مركزى جمهورى اسلامى ايران. }
\end{aligned}
$$

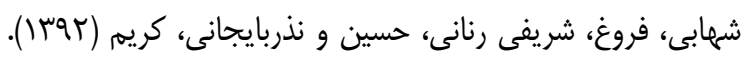

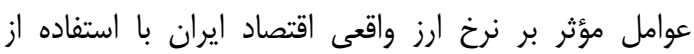

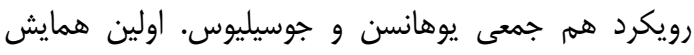

$$
\begin{aligned}
& \text { الكترونيكى ملى هُهم انداز اقتصاد ايران }
\end{aligned}
$$

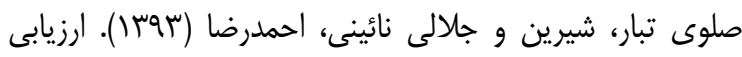

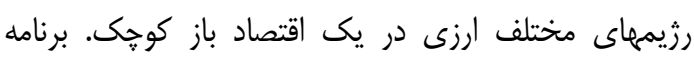

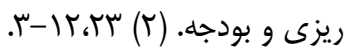

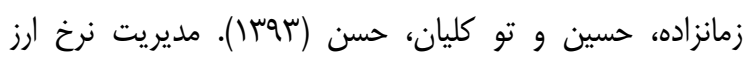

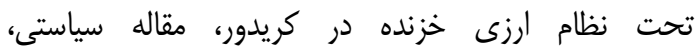

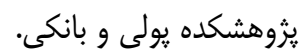

$$
\begin{aligned}
& \text { خيابانى، ناصر و كلاهى (ادسا). يكسان سازى نرخ ارز و اثر آن }
\end{aligned}
$$

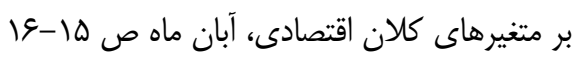

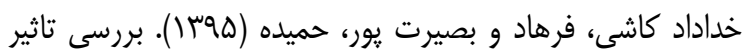

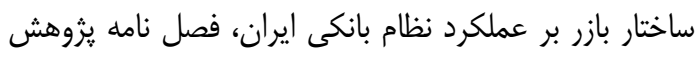

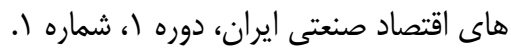

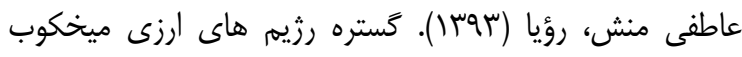

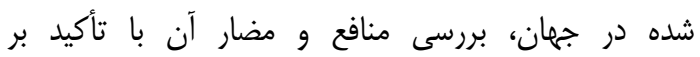

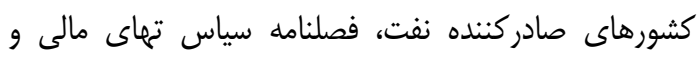

$$
\begin{aligned}
& \text { اقتصادى، سال ז، شماره ه، بعار. }
\end{aligned}
$$

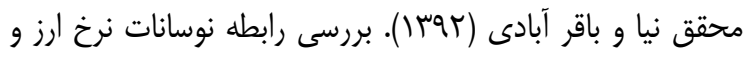

$$
\begin{aligned}
& \text { بازده صنعت بانكدارى در بورس اوراق بهادار تهران. }
\end{aligned}
$$

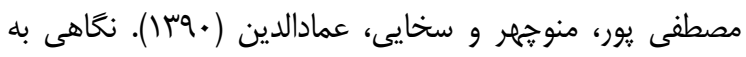

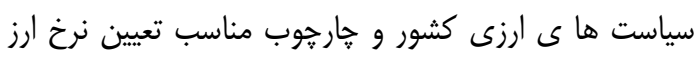

$$
\begin{aligned}
& \text { مجله اقتصادى، ماهنامه بررسى مسائل و سياست هاى }
\end{aligned}
$$

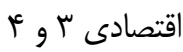

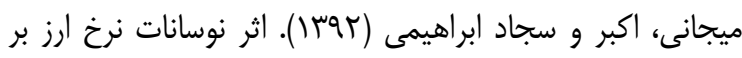

$$
\begin{aligned}
& \text { رشد بهره ورى در كشورهاى در حال توسعه با لحاظ سطح }
\end{aligned}
$$

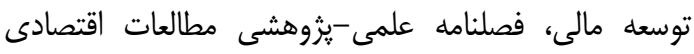

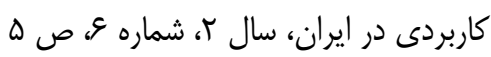

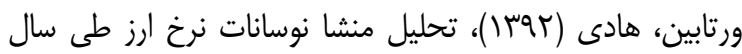

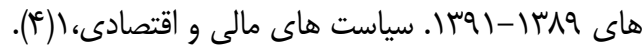

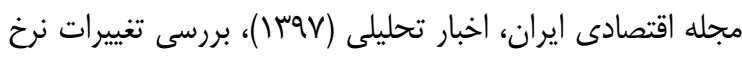

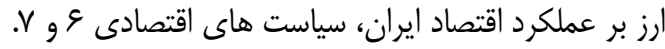

Agbeja, O., Adelakun, O. J., \& Udi, E. E.

(2016). Empirical Analysis of Counterparty Risk and Exchange Rate Risk Management on the Performance of Deposit Money Banks in Nigeria (20092013). Journal of Accounting and Finance, 16(2), P. 106.

Akonji Danmola, Rasaq (2013). The 


$$
\begin{aligned}
& \text { فصلنامه علمى رهيافتى در مديريت بازر كانى }
\end{aligned}
$$

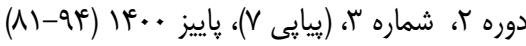

Trade?; OECD Trade Policy Papers, 119. Nyandema،( 2016 ) : The Influence Of Foreign Exchange Rate Fluctuations On The Financial Performance Of Commerial Banks Listed At The Nairobi Securities Exchange, British Journal of Marketing Studies, vol . 4 , No. 3 , PP . 1 -11 .

Ramos, Raquel Almeida (2012). Intersections between exchange rate and inflation plocies in IMF Recommendations; the international policy center for inclusive growth UNDP and the Government of Brazil .

Tadesse, G. (2015). The Impact of Exchange Rate on the Profitability of Commercial Banks in Ethiopia (Doctoral dissertation AAU) .

Rivero, S., \& Herrera, M. (2014). Exchange-rate regimes and inflation: An empirical evaluation. Working Papers on International Economics and Finance, 118

Verma , P . R . I . T . I . ( 2016 ), The Impact Of Exchange Rates And Interest Rates On Bank Stock Returns : Evidence From US Banks. Studies in Business and Economics , 11 (1) , 124 - 139 .

Zhao, G., (2013), Exchange rate risk and the equity performance of financial intermediaries. International Review of Financial

Analysis,282-29 
نوروزى و همكاران : ارزيابى استراتزيكك اثرات نظام ارزى بانككها و يكسانسازى نرخ ارز بر عملكرد بانكك تجارت 